Volume 54

Issue 2 Volume 54, Issue 2 (Winter 2017)

Special Issue: Introduction to the Law and

Markets: Regulating Controversial Exchange

Article 8

Guest Editors: Kimberly Krawiec, Poonam Puri

and Mitu Gulati

6-1-2017

\title{
The Philosopher and the Developer: Pluralist Moral Theory and the Law of Condominium
}

Jason Leslie

University of British Columbia

Follow this and additional works at: https://digitalcommons.osgoode.yorku.ca/ohlj

Part of the Law and Philosophy Commons, and the Property Law and Real Estate Commons Article

This work is licensed under a Creative Commons Attribution-Noncommercial-No Derivative Works 4.0 License.

\section{Citation Information}

Leslie, Jason. "The Philosopher and the Developer: Pluralist Moral Theory and the Law of Condominium." Osgoode Hall Law Journal 54.2 (2017) : 511-558.

https://digitalcommons.osgoode.yorku.ca/ohlj/vol54/iss2/8

This Article is brought to you for free and open access by the Journals at Osgoode Digital Commons. It has been accepted for inclusion in Osgoode Hall Law Journal by an authorized editor of Osgoode Digital Commons. 


\title{
The Philosopher and the Developer: Pluralist Moral Theory and the Law of Condominium
}

\begin{abstract}
This paper analyzes the evolving law of condominium from the perspective of the moral philosophy of property, focusing in particular on neo-Aristotelian value or pluralist ethics. By combining aspects of traditional property law, corporate law, and municipal politics, condominium provides a flexible tool for ownership and private land use planning. Condominium, however, also poses novel and unique challenges to both legal doctrine and the very meaning of private property. After describing and comparing the pluralist approach to moral philosophy of property and the approach of its main rivals-deontology and utilitarianism -the paper describes how condominium is understood by each approach and analyzes in detail current legislation and court decisions regarding condominium in light of these approaches.

The paper concludes that courts and legislatures have been alternating between deontological approaches and pluralist approaches to condominium, with a general trend in recent developments away from the deontological approaches and towards pluralist approaches. The thesis tentatively suggests that on the whole, pluralist approaches lead to more just and equitable results in condominium, and suggests further avenues for study.

\section{Keywords}

Condominiums--Law and legislation; Property--Philosophy

\section{Creative Commons License}

(c) (i) $\Theta$

This work is licensed under a Creative Commons Attribution-Noncommercial-No Derivative Works 4.0 License.
\end{abstract}




\title{
The Philosopher and the Developer: Pluralist Moral Theory and the Law of Condominium
}

\author{
JASON LESLIE*
}

This paper analyzes the evolving law of condominium from the perspective of the moral philosophy of property, focusing in particular on neo-Aristotelian value or pluralist ethics. By combining aspects of traditional property law, corporate law, and municipal politics, condominium provides a flexible tool for ownership and private land use planning. Condominium, however, also poses novel and unique challenges to both legal doctrine and the very meaning of private property. After describing and comparing the pluralist approach to moral philosophy of property and the approach of its main rivals-deontology and utilitarianism-the paper describes how condominium is understood by each approach and analyzes in detail current legislation and court decisions regarding condominium in light of these approaches.

The paper concludes that courts and legislatures have been alternating between deontological approaches and pluralist approaches to condominium, with a general trend in recent developments away from the deontological approaches and towards pluralist approaches. The thesis tentatively suggests that on the whole, pluralist approaches lead to more just and equitable results in condominium, and suggests further avenues for study.

Le présent article analyse l'évolution du droit des condominiums sous l'angle de la philosophie morale de la propriété et se concentre tout particulièrement sur la perspective néoaristotélicienne ou « éthique pluraliste ». En combinant divers aspects du droit des biens traditionnel, du droit des sociétés et de la politique municipale, le condominium représente un outil souple destiné à la propriété ainsi qu'à l'aménagement du territoire privé. Ce faisant, il pose de nouveaux défis singuliers tant sur le plan de la doctrine juridique qu'au niveau du sens même de la propriété privée. L'article expose l'approche pluraliste de la philosophie morale de la propriété et la compare à l'approche de ses principales théories rivales, à

* $\quad$ BA (Hons) (Simon Fraser University), JD (Columbia), LLM (University of British Columbia), PhD Student at the University of British Columbia. 
savoir la déontologie et l'utilitarisme. Il illustre ensuite la manière dont chaque approche appréhende le condominium, puis analyse en détail la législation en vigueur et les décisions judiciaires visant le condominium à la lumière de ces approches.

L'article conclut que les tribunaux et les parlements abordent la question des condominiums en alternant les approches déontologiques et les approches pluralistes et que la tendance actuelle semble globalement délaisser les approches déontologiques au profit des approches pluralistes. Cette thèse tend à indiquer que, dans l'ensemble, les approches pluralistes aboutissent à des résultats plus justes et équitables dans le secteur des condominiums. D'autres pistes d'étude sont également présentées.

I. GENERAL ATTRIBUTES OF CONDOMINIUM.

II. MORAL THEORIES OF PROPERTY AND THEIR APPLICATION TO CONDOMINIUM .....................518

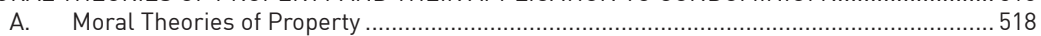

1. Human flourishing in Pluralist Moral Theory .............................................. 521

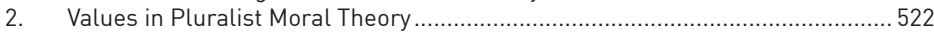

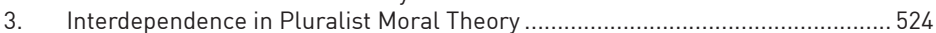

4. Practical Reason in Pluralist Moral Theory .................................................. 525

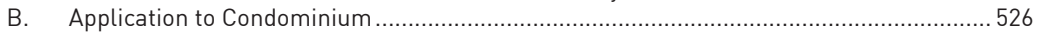

III. A MORAL THEORETIC ANALYSIS OF CONDOMINIUM DISPUTES ............................................ 530

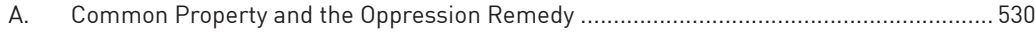

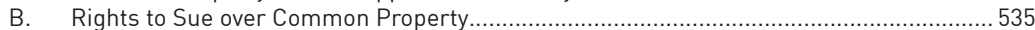

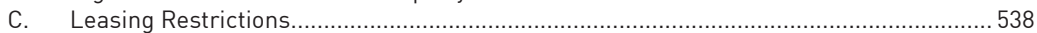

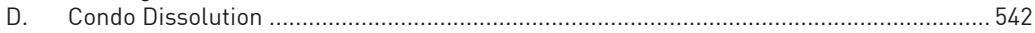

THE PAST HALF-CENTURY HAS SEEN RAPID DEVELOPMENT of condominium as a new form of land ownership. In major urban centres in Canada, the 'condo' is now a central feature of residential property ownership. ${ }^{1}$ Condominium enables the purchase of an affordable home that has many of the features of a traditional, unitary lot. However, condominium presents new and unique challenges. Purchasing a unit means entering into a democratic community of owners with mutual rights and responsibilities and sharing in the running and maintenance of a complex. As a new form of property, condominium raises issues about the

1. See Douglas Harris, "Condominium and the City: The Rise of Property in Vancouver" (2011) 36.3 Law \& Soc Inquiry 694. Harris provides an analysis of the prevalence of condominium in Vancouver. For an analysis on the prevalence of condominium in Toronto, see Gillad Rosen \& Alan Walks, "Castles in Toronto's Sky: Condo-ism as Urban Transformation" (2014) 37.3 J Urb Aff 289 at 289. The authors note that "Toronto has experienced a tremendous surge in condominium development over the last 40 years and especially during the last decade." See Audrey M Loeb, Condominium Law and Administration, 2nd ed (Toronto: Carswell, 1999). 
nature of ownership that reflect the increasing complexity of society, its economy, and its legal institutions.

This article explores the connections between the condominium form and associated legal doctrine, on the one hand, and the moral philosophy of property, on the other. Until recently, most philosophical work on the moral justification of private property rights has focused either on utilitarian consequentialist theories or deontological rights-based theories. However, in recent years there has been a revival of interest in neo-Aristotelean "value ethics" and its potential application to property theory. Condominium, with its community focus and complex structure, provides a useful case study for examining the explanatory power of the neo-Aristotelean approach and comparing it with more traditional approaches.

In this regard I draw inspiration from Gregory Alexander, who along with his colleague Eduardo Peñalver has led a discussion to reimagine property law from a neo-Aristotelean perspective. ${ }^{2}$ Alexander and Peñalver outline how "value ethics" applies to property law generally and consider its implications for expropriation, ${ }^{3}$ nuisance law, ${ }^{4}$ land use regulation, ${ }^{5}$ the right to exclude, ${ }^{6}$ redistribution of wealth, ${ }^{7}$ intellectual property, ${ }^{8}$ and collective ownership in general. ${ }^{9}$ Here, I review their approach — which I call "pluralist property theory" - and add to the analysis by applying it to condominium property. Additionally, I analyze how court and legislatures have addressed issues within condominium property and consider which moral theory aligns most closely with the results.

Part I describes the general attributes of condominium as a form of ownership, and outlines how it differs from more conventional fee simple ownership. Part II then presents an overview of the neo-Aristotelean approach, which I call "pluralist moral theory," ${ }^{10}$ providing a description of this family of theories and comparing them to utilitarian and deontological approaches. Part

2. See e.g. Gregory S Alexander \& Eduardo M Peñalver, An Introduction to Property Theory (New York: Cambridge University Press, 2012); Gregory S Alexander, "The Social-Obligation Norm in American Property Law” (2009) 94:4 Cornell L Rev 745; Gregory S Alexander, “The Complex Core of Property" (2009) 94:4 Cornell L Rev 1063. See also Eduardo M Peñalver, "Land Virtues" (2009) 94:4 Cornell L Rev 821.

3. Alexander \& Peñalver, ibid, ch 8.

4. Alexander, "The Social Obligation Norm in American Property Law," supra note 2 at $779 \mathrm{ff}$.

5. Ibid at $791 \mathrm{ff}$.

6. Alexander \& Peñalver, supra note 2, ch 7.

7. Ibid, ch 6 .

8. Ibid, ch 9 .

9. Gregory S Alexander, "Governance Property" (2012) 160:7 U Pa L Rev 1853.

10. "Pluralist moral theory" is different from "pluralist property theory." Pluralist moral theory refers to the general theory applicable to all moral questions, whereas pluralist property theory is specific to the application of pluralist moral theory to questions regarding property. 
II also explores how the utilitarian, deontological, and pluralist approaches understand and interpret condominium. Part III applies these approaches to a number of complex condominium disputes. The analysis reveals that the courts are using deontological and pluralist approaches in their reasoning. Finally, in the concluding Part IV, the article suggests that pluralist moral theory can help explain some of the court case outcomes as well as provide a new, useful perspective on condominium property. It also suggests directions for further research and reaches some preliminary normative conclusions about the superiority of the pluralist approach.

\section{GENERAL ATTRIBUTES OF CONDOMINIUM}

Condominium legislation swept across Canada, the United States, and a number of other common law jurisdiction in the 1960 's, ${ }^{11}$ and is a now central feature of residential ownership in major urban centres in Canada. ${ }^{12} \mathrm{~A}$ recent poll suggests that condominium is the second-most sought after form of home ownership in Ontario, after detached fee simple housing. ${ }^{13}$ Condominium provides a way to own property in a form that is similar to a traditional detached lot, but more affordable and suitable for a high-density environment. It enables home ownership and an urban or suburban lifestyle that is more secure than renting and offers more flexibility than membership in a cooperative. By contrast to cooperative membership, each condominium unit can be financed independently and usually can be sold without input from the other members of the complex.

Condominium subdivides land into individually-owned "units" and collectively-owned "common areas." ${ }^{14}$ A developer wishing to create a new condominium must first obtain government approval in a manner akin to obtaining approval for a regular subdivision. ${ }^{15}$ The developer then files a land

11. Condominium legislation swept across Canada, the United States, and a number of other common law jurisdiction in the 1960s. See Harris, supra note 1 at 695.

12. See Harris and Rosen \& Walks, supra note 1.

13. Sean Simpson, "Condos Rank as Second Most Popular Real Estate Choice for Prospective Ontarian Home Buyers," Ipsos Reid (10 July 2014), online: <http://ipsos-na.com/news-polls/ pressrelease. aspx?id $=6559>$.

14. Under the Ontario Condominium Act, SO 1998, c 19, "condominium" describes the general property form, "declaration" describes the basic document that creates the condominium, and "condominium corporation" describes the entity that represents the owners and administers the property. BC's legislation is the Strata Property Act, SBC 1998, c 43 [SPA] and it uses "strata," "strata plan," and "strata corporation," respectively. For most purposes these terms are equivalent and I will use them interchangeably unless the context requires otherwise.

15. See e.g. Loeb, supra note 1 at 2-1-2-4. 
title "declaration" that acts like a "constitution" for the development. It defines the "type" of condominium development, ${ }^{16}$ outlines the dimensions of each unit and of the common areas, sets out a schedule of the maintenance contributions for each unit, and provides basic rules and restrictions governing the complex. ${ }^{17}$ The declaration also defines any "limited common property" 18 or exclusive use areas $^{19}$ in the complex. These areas are portions of the common property that are designated for the exclusive use of one or more unit owners, but are not part of those owners' individual titles.

Once the declaration is filed, the individual unit titles are created and a condominium corporation is formed. Initially, the developer is the owner of all the individual units and the common property, and is the sole member of the condominium corporation. When a purchaser buys an individual unit, that person obtains three things: (1) title to the individual unit as defined in the declaration; (2) an undivided interest in the common property of the condominium along with an obligation to contribute to its maintenance; and (3) membership in the condominium corporation. ${ }^{20}$ These three items come as a package and cannot be separated. Both individual condominium units and common areas are real property for all relevant purposes. ${ }^{21}$ Ownership of a unit also comes with restrictions and duties specified by statute, in the declaration, and in valid rules and bylaws that are passed from time to time by the condominium corporation. Courts have an active role in overseeing the governance of the condominium, as rules, bylaws, and decisions of the corporation may be found invalid if they are unreasonable or significantly unfair. ${ }^{22}$ In Ontario, acts of the corporation

16. In BC there are two types of plans: regular strata plans and bare land strata plans. See Mike Mangan, The Condominium Manual: A Comprehensive Guide to the Strata Property Act (Vancouver: BC Real Estate Association, 2010) at 15; SPA, supra note 14, s 1 ("bare land strata plan"). In Ontario, there are several different types, including "common elements condominiums" and "vacant land condominiums." See Condominium Act, supra note 14, ss $138-44,155-63$.

17. See Condominium Act, supra note 14, s 7; SPA, supra note 14, s $244 \mathrm{ff}$.

18. SPA, supra note 14, ss 1, 73-77 ("limited common property").

19. Condominium Act, supra note 14, s 7(2)(f). Unlike the BC legislation, the Ontario Act does not have a defined term for exclusive use areas, but does have a similar concept.

20. Strata Title Act, SBC 1998, c 43, s 2 [STA]; Condominium Act, supra note 14, s 11.

21. Condominium Act, supra note 14, s 10. In Ontario the wording of section 10 makes it clear that both individual units and common areas are real property. In BC, SPA, supra note 14, s 239 states "[1] and may be subdivided into 2 or more strata lots by the deposit of a strata plan in a land title office." By implication, a strata lot is legally considered "land."

22. SPA, supra note 14, s 164; Condominium Act, supra note 14, ss 56, 58, 135. 
may also be declared invalid if they are oppressive. ${ }^{23}$ Finally, voting rights in the corporation are generally fixed by statute at one vote per unit. ${ }^{24}$

In Ontario, the declaration may contain certain restrictions on the nature of the development. In particular, a declaration may contain "conditions or restrictions with respect to gifts, leases and sales of the units and common interests" 25 and "conditions or restrictions with respect to the occupation and use of the units or common elements." ${ }^{26}$ In British Columbia (BC), there is no statutory authority for such restrictions in the strata plan. Instead, the Strata Property Act permits bylaw restrictions on leasing ${ }^{27}$ and "for the control, management, maintenance, use and enjoyment" of strata lots and common property. ${ }^{28}$ The Strata Property Act specifically prohibits any restrictions on selling, mortgaging, or otherwise transferring title to units. ${ }^{29}$

The corporation has the responsibility for managing and repairing the common property. The corporation also collects levies from unit owners, enacts and enforces policies and bylaws, and manages the financial affairs of the complex. While the day-to-day affairs of the corporation are run by an elected council, major decisions must be put to a vote of the individual unit owners and require majority, super-majority, or unanimous approval, depending on the type of decision. As a separate legal entity, the condominium corporation has the power to sue and be sued, as well as to enter into contracts, both with unit owners and with third parties. Under some circumstances, a condominium corporation has the power to bring an action on behalf of the members of the condominium corporation. In Ontario, this action requires only majority approval by the condominium corporation's board of directors; ${ }^{30}$ in $\mathrm{BC}$, the action can only be taken on a three-quarter supermajority vote of all the owners who will be represented in the lawsuit. ${ }^{31}$

23. Condominium Act, SO 1998, c 19, s 135.

24. Ibid, s 51; Strata Property Act, SBC 1998, c 43, s 53. In BC, an exception may be made for non-residential units, which may have a different voting entitlement. See ibid, ss $247-48,264$.

25. Condominium Act, supra note 14, s 7(4)(c).

26. Ibid.

27. SPA, supra note 14 , s $141(2)$.

28. Ibid, s 119(2).

29. Ibid, s 121(1)(c).

30. Condominium Act, supra note 14, s 23.

31. STA, supra note 20, ss 171-72. 
A condominium complex can be terminated either by vote of the owners or on application to court. In Ontario, a decision to terminate requires only a supermajority vote. ${ }^{32} \mathrm{In} \mathrm{BC}$, such decisions require a unanimous vote. ${ }^{33}$ Once terminated, the $\mathrm{BC}$ legislation specifically provides that the former owners become tenants in common of the entire property, ${ }^{34}$ though on a court-ordered termination the court has the power to vary this provision. ${ }^{35}$ In Ontario, the legislation specifies that on termination the assets of the corporation remaining after all debts and claims are paid shall be distributed proportionally to the former unit owners. ${ }^{36}$

The condominium regime attempts to resolve the challenges of multiple ownership by altering traditional property rights and creating an organizational form that has some aspects of property co-ownership, some aspects of a business corporation, and some aspects of a municipal government. A strata lot comes with rights, duties and responsibilities that would not otherwise accompany fee simple title. The purchaser of a unit becomes a member of a community that can impose duties, levy taxes, restrict the owner's behavior, and impinge on the integrity of the lot. In return, the owner participates in governing the complex.

Although it involves elements of both democratic and corporate governance, condominium is primarily understood as a form of property. Having reviewed the general features of this property form, I now turn to a review of moral theories of property and their application to this new model of ownership.

32. See Condominium Act, supra note 14, s 122. With regard to termination in Ontario, a supermajority is an $8 / 10$ majority vote of both owners and anyone who has a claim registered against property in the complex.

33. STA, supra note 20, s 269, 272ff. However, recent amendments not yet in force will change termination to a supermajority vote. Bill 40, Natural Gas Development Statutes Amendment Act, 4th Sess, 40th Leg, BC, 2015, ss 37-55 (assented to 17 November 2015).

34. STA, supra note 20, s 272.

35. Ibid, s 285.

36. Condominium Act, supra note 14, s 129. This implies that on termination the former unit owners become tenants in common over the property. See Royal Insurance Co of Canada $v$ Middlesex Condominium Corp No 173 (1998), 37 OR (3d) 139, [1998] OJ No 251. 


\section{MORAL THEORIES OF PROPERTY AND THEIR APPLICATION TO CONDOMINIUM}

\section{A. MORAL THEORIES OF PROPERTY}

For many years, utilitarian and deontological approaches have dominated discussions on property theory. ${ }^{37}$ The pluralist approach, while it draws on Aristotelean ideas, is a latecomer in the modern dialogue. As such, it is useful to review utilitarian and deontological theory briefly, then move on to a more detailed description of the pluralist alternative.

Utilitarian theories postulate that one privileged metric - "utility" - alone has intrinsic moral value. In some theories, utility is measured in the subjective experience of individuals, using a variable such as happiness or preference-satisfaction; other theories use a more objective measure such as welfare or wealth. ${ }^{38}$ In either case, a utilitarian moral theory requires society to take whatever actions and prescribe whatever rules will maximize utility.

Utilitarianism has its roots in the political philosophies of Jeremy Bentham and John Stuart Mill. ${ }^{39}$ In the context of modern property theory, utilitarianism is expressed primarily through the lens of law and economics. ${ }^{40}$ Under this lens, models of rational economic behavior and human interaction are applied to legal doctrine, either in a positive mode (to explain why the law is the way it is) or in a normative mode (to justify existing legal doctrine or make recommendations for change). Law and economics tends to favour property systems that are predominantly private and allow for a high degree of alienability. According to

37. See e.g. Alexander \& Peńalver, supra note 2 at xi; Margaret Jane Radin, Reinterpreting Property (Chicago: University of Chicago Press, 1993) at 35; Jeremy Waldron, The Right to Private Property (Oxford: Clarendon Press, 1988).

38. Richard Posner distinguishes his approach from traditional utilitarianism by adopting "wealth" as the appropriate metric, rather than "happiness" or "preference satisfaction." See Richard Posner, "Utilitarianism, Economics, and Legal Theory" in The Economic Structure of the Law: The Collected Economic Essays of Richard Posner, vol 1 (Cheltenham, UK: Edward Elger Publishing, 2000) 140.

39. See Jeremy Bentham, "Security and Equality of Property" in C B Macpherson, ed, Property: Mainstream and Critical Positions (Toronto: University of Toronto Press, 1978) 39; John Stuart Mill, "Of Property" in ibid at 75.

40. Alexander \& Peñalver, supra note 2 at 18 . The authors state: "Thoroughgoing and systematic utilitarian analyses of property are largely a product of the twentieth-century movement known as Law and Economics" [emphasis in original]. The Oxford Dictionary of Philosophy also notes that "utilitarianism is, in effect, the view of life presupposed in most modern political and economic planning, when it is supposed that happiness is measured in economic terms." See Simon Blackburn, The Oxford Dictionary of Philosophy, 2nd revised ed (Oxford: Oxford University Press, 2008) at 490-91 ("utilitarianism"). 
these theories, such property systems are the most likely to lead to the greatest amount of overall wealth or preference satisfaction because resources will tend to end up in the hands of those who value them the most. ${ }^{41}$

Where utilitarian theories ground moral reasoning in a one-dimensional metric, deontological theories ground moral reasoning in a privileged rule or set of rules about how individuals ought to behave. In the case of property, this is most often expressed in terms of a privileged moral right or set of rights that command respect from others and impose restraints on their behaviour. ${ }^{42}$ For most such theories, rights are individualistic. Only a person has rights; collectives do not have rights per se, although the recognition of individual rights may give rise to collective obligations or privileges. Moreover, the consequences of particular actions, rules or systems on the aggregate utility or welfare of individuals are of either secondary or of no importance. A potential change in property rights may lead to an overall increase in aggregate utility, but if that change violates the rights of some of the parties in the system, it cannot be justified.

Deontological theories about property are often linked to John Locke and Immanuel Kant. ${ }^{43}$ Locke postulated a natural right to private property in the products of one's own labour; Kant saw private property as essential to promoting individual freedom. Jeremy Waldron usefully describes a rights-based theory for private property as one that "takes some individual's interest (or the interests of some or all individuals severally) as a sufficient justification for holding others (usually governments) to be under a duty to create, secure, maintain, or respect an institution of private property." ${ }^{44}$ In particular, this definition helpfully distinguishes right-based theories from utilitarian theories: "[u]tilitarian arguments do not count as rights-based because they do not usually regard individual interests taken one-by-one as political justifications for anything." ${ }^{45}$

Pluralist theories, unlike utilitarian and deontological theories, do not attempt to identify a fixed, single value or set of values to underlie all moral reasoning. Instead, pluralist theories accept that moral questions are irreducibly complex and involve an open-ended set of revisable and context-sensitive human values. Rather than providing formulae that can resolve all moral issues, pluralist theory

41. Harold Demsetz, "Toward a Theory of Property Rights" (1967) 57:2 Am Econ Rev 347.

42. It is also possible to frame deontological moral theories in terms of duties rather than rights. However, most property theory has been examined in terms of rights. See Waldron, supra note 37 at $64 \mathrm{ff}$.

43. See extended discussion in Waldron, supra note 37. See Alexander \& Peñalver, supra note 2 for discussions of Locke and Kant.

44. Waldron, supra note 37 at 87.

45. Ibid at 89 . 
sets up a framework for identifying and debating moral questions. It envisions moral discourse as an ongoing conversation and a process of discovery rather than as the application of fixed principles.

However, pluralist theory need neither collapse into moral relativism, nor accept that morality is just politics and the posturing of interest groups. The theory can take seriously the idea that there are objective limits to moral reasoning that apply universally. At the same time, pluralist theory can recognize that moral questions sometimes involve complex interactions of incommensurable human values that may not always have one fixed, objectively verifiable answer.

The main forerunner of the modern pluralist movement is the American pragmatist John Dewey. ${ }^{46}$ Modern proponents include Alasdair MacIntyre ${ }^{47}$ and Martha Nussbaum ${ }^{48}$ (the latter in the form of a "human capabilities" approach to morality). In the area of property, Gregory Alexander and Eduardo Peñalver have adopted a form of Nussbaum's approach, ${ }^{49}$ and both Hanoch Dagan and Joseph Singer have presented theories that are pluralist in outlook. ${ }^{50}$

While these pluralist theories have their differences, it is possible to identify four key elements. Not all pluralist theories have all of these elements, nor are there any necessary and sufficient conditions for a theory to be a pluralist theory. Nevertheless, these key elements are common to many pluralist theories, and one would be hard pressed to consider a theory that does not have most of them to be pluralist. The four elements are:

- Reference to an umbrella concept such as "human flourishing" or another similar idea to describe the overall purpose of a moral system;

- Incorporation of an open-ended and revisable list of incommensurable human "values" that both constitute and promote the overall purpose;

- Recognition of the interdependence of individuals and community, to the point that the interests of the community as a whole carry moral weight in addition to that of the individuals in the community; and

46. See Stephen Carden, Virtue Ethics: Dewey and MacIntyre (New York: Continuum, 2006).

47. Ibid.

48. Martha Nussbaum, "Capabilities as Fundamental Entitlements: Sen and Social Justice" (2003) 9 Feminist Economics 33.

49. Gregory S Alexander \& Eduardo Peñalver, supra note 2, ch 5.

50. Hanoch Dagan, Property: Values and Institutions (Oxford: Oxford University Press, 2011); Joseph Singer, "Democratic Estates: Property Law in a Free and Democratic Society" (2009) 94:4 Cornell L Rev 1009. 
- Adoption of a context-oriented, "practical reason" approach to moral questions that involves a low level of abstraction and a high sensitivity to particular circumstances.

Each of these elements merits a brief discussion.

\section{HUMAN FLOURISHING IN PLURALIST MORAL THEORY}

The notion of human flourishing derives from Aristotle. ${ }^{51}$ The phrase is a translation of the term "eudaimonia," postulated by Aristotle as the ultimate end of the good life. While the term is sometimes translated as "happiness" or "well-being," commentators generally regard Aristotle's meaning more broadly. Rather than referring to a purely subjective experience, eudaimonia captures an overall objective state of harmony and can be applied not only to individuals but to entire communities and to society as a whole. ${ }^{52}$

Whereas utility is "thin," resting on the subjective welfare of individuals, human flourishing is "thick," involving both the objective and subjective, the individualistic and collective. ${ }^{53}$ It cannot be reduced to or explained by a single metric or a small set of human interests. As used by pluralist theorists, human flourishing is not so much a unitary concept as a rhetorical device pointing towards an intuitive feel for "the good." It is meant to appeal to something deep in human nature: to that which gives rise to the spiritual impulse, to humanitarian compassion, and to a sense that there is a rich and multi-dimensional meaning

51. See e.g. Roger Crisp \& Michael Slote, eds, Virtue Ethics (Oxford: Oxford University Press, 1997 ) at 2 ("[T] he ancient greek philosopher, Aristotle... has been the main source of inspiration for modern virtue ethicists."); Nussbaum, supra note 49 at 54 (stating that her vision of pluralist ethics, a "capabilities" approach, "need[s] to adopt a political conception of the person that is more Aristotelean than Kantian"); Gregory S Alexander \& Eduardo Peñalver, supra note 2 at 80 (stating that pluralist value ethics "draws inspiration from the political and moral theories of Aristotle and Thomas Aquinas. Though it departs in significant ways from those classical theories, enough debt to Aristotle remains that we will sometimes refer to the theory simply as 'Aristotelean'.")

52. Alexander $\&$ Peñalver, supra note 2 at 81 . See also Carden, supra note 47 at 80 . Carden writes: "Aristotle conceived of the virtues as means to and constitutive of human flourishing; that is, given the nature of man, the virtues are the key to the good life, or eudaimonia."

53. In comparing the theories of two prominent early modern philosophers working in the value ethics tradition, Alastair MacIntyre and John Dewey, Carden notes that: "Dewey and MacIntyre come to much the same conclusion about human flourishing - that the virtues are constitutive of the good life, both for the individual and the community, since these are ultimately inseparable." See Carden, supra note 47 at 101. 
to human life. ${ }^{54}$ As such, while philosophers can invoke human flourishing as a basis for moral reasoning and can theorize its contents and implications, it may be beyond a complete intellectual description.

Human flourishing can be interpreted as an absolute or relative concept. In its absolute form, as originally conceived by Aristotle, human flourishing provides a fuzzy but objective backdrop against which to evaluate any human being and any human society. ${ }^{55}$ In its relative form, as conceived by some modern theorists, human flourishing does not have an objective content that applies to all persons and all societies, but instead is relative to culture. ${ }^{56}$

\section{VALUES IN PLURALIST MORAL THEORY}

Reasoning directly from human flourishing to any particular result is impossible. Instead, moral reasoning in the pluralist tradition is mediated through values that capture a specific dimension of human flourishing and render it more precise in a given context. No single value can encapsulate all of human flourishing. Moreover, values are incommensurable: they cannot be reduced to or defined in terms of one another, nor can they be placed in a fixed hierarchy. This is the crux of the pluralist critique of both utilitarianism and deontology. Following Aristotle, pluralists generally maintain that ethical reasoning, and thus values, arise from the practice of ethical behavior and use of values within a specific

54. Alexander \& Peñalver note that "[f]lourishing is an irreducibly complex concept that is constituted by numerous plural and incommensurable goods." They also point out that "Aristotle recognized that there is disagreement about what constitutes happiness (flourishing), and he dismisses several plausible candidates, including pleasure." See Alexander \& Peñalver, supra note 2 at 81 . MacIntyre, with some religious overtones, posits human flourishing as the goal of human existence or the reason for its being, while Dewey ties the notion of human flourishing to a complex biological and evolutionary process of growth. See Carden, supra note 47 at 98-101. For an interesting take on value ethics that uses the analogy of physical health to provide a basis for understanding human flourishing, see Sam Harris, The Moral Landscape: how science can determine moral values (New York: Free Press, 2010).

55. Alexander \& Peñalver, supra note 2.

56. Eduardo Peñalver has expressed sympathies with the relativist approach. See Eduardo M Peñalver, "Land Virtues" (2009) 94:4 Cornell L Rev 821 at 866 (adopting a view consonant with the cultural relativism of Alasdair MacIntyre). 
context. ${ }^{57}$ The need for a contextual approach that incorporates the complexities of human life takes a front seat in their reasoning..$^{58}$

Alexander and Peñalver note that "the values... are plural and incommensurable" and that it is not generally possible to compensate adequately for a lack of any value by an excess of another value. ${ }^{59}$ Hanoch Dagan follows an observation made by Isaiah Berlin that "human life is replete with competing values that cannot be reconciled and with legitimate wishes that cannot be truly satisfied. Because some values intrinsically conflict and because we cannot have everything we want, explains Berlin, "[t]he need to choose, to sacrifice some ultimate values to others, turns out to be a permanent characteristic of the human predicament." 60

Importantly, the list of values is open-ended. Pluralist theorists do not expect a final list of values exhausting the possibilities of moral consideration. Instead, they rely on the notion of 'human flourishing' to help identify the values applicable in any particular situation, and remain open to adding, refining, and developing those values as needed. In his description of Dewey's ethics, Stephen Carden notes that "[v]alues are objects or events that have been judged worthy of pursuit or avoidance; thus they too are dependent on the conditions leading to and resulting from objects or events to be enjoyed. None is universal or eternal,

57. See e.g. Stephen Carden, supra note 47 at 60-64 (comparing MacIntrye's and Dewey's rejections of both consequentialist and deontological theories as being too inflexible and "rule-based").

58. See e.g. John Dewey, "Three Independent Factors in Morals" in Jo Ann Boydston, ed, The Later Works of John Dewey: 1925-1953 (Carbondale: Southern Illinois University Press, 2008), vol 5 at 288. Dewey states:

A moral philosophy which should frankly recognize the impossibility of reducing all the elements in moral situations to a single commensurable principle, which should recognize that each human being has to make the best adjustment he can among forces which are genuinely disparate, would throw light upon actual predicaments of conduct and help individuals in making a juster estimate of the force of each competing factor... In taking attention away from rigid rules and standards it would lead me to attend more fully to the concrete elements entering into the situations in which they have to act.

59. Alexander \& Peñalver, supra note 2 at 90.

60. Dagan, supra note 51 at 70-71, quoting Isaiah Berlin, Four Essays on Liberty (London: Oxford University Press, 1969) at 1-li. 
for each is a result of particular temporal conditions." ${ }^{\prime 1}$ This particularity enables legal traditions based in a pluralist notion of ethics to remain flexible and evolve over time. According to Dagan, "law is 'a going institution'; it is, in John Dewey's words, 'a social process, not something that can be done [sic] or happen at a certain date.' As a dynamic institution, law is structured to be an 'endless process of testing and retesting'; thus understood, law is a great human experiment continuously seeking improvement." ${ }^{\prime 2}$

\section{INTERDEPENDENCE IN PLURALIST MORAL THEORY}

Alexander and Peñalver note that Aristotle stated seven times: "a human being is by nature a political animal." ${ }^{33}$ What Aristotle meant by this, and about which most pluralist theorists agree, is that individuals and communities are interdependent. ${ }^{64}$ People need a well-functioning society to secure their well-being, to develop a sense of identity and purpose, and to grow into mature and conscientious moral actors. A human community obviously cannot exist without people, but at the same time, people cannot exist, except in a very rudimentary and coarse way, without a community. How people develop, how they perceive themselves, and how they set their goals, desires, and preferences are all heavily influenced by their society. Communities are not just made of people; people are made of communities. ${ }^{65}$

Because of this interdependence, pluralist moral theory sees individual and collective interests not as primarily in conflict, but as mutually reinforcing.

61. Carden, supra note 47 at 53. See also Martha Nussbaum, supra note 49 at 41 and Gregory Alexander, "The Social-Obligation Norm in American Property Law" (2008-2009) 94: 4 Cornell L Rev 745 at 765 . Nussbaum describes her proposed list of capacities as values as being "open ended," anticipating the need to "undergo further modification." Alexander notes that: "[ $\mathrm{t}]$ here is amble room for robust debate about exactly what capacities are the crucial components of human flourishing."

62. Dagan, supra note 51 at xxi, citing John Dewey, "My Philosophy of Law" in Julius Rosenthal Foundation, My Philosophy of Law; Credos of Sixteen American Scholars (Boston: Boston Law Book, 1941) 71 at $73,77$.

63. Alexander $\&$ Peñalver, supra note 2 at 80 .

64. See Alexander \& Peñalver, supra note 2 at 80. Alexander and Peñalver expand on Aristotle’s conception as follows:

Empirically, part of his meaning is that humans are social creatures and that we characteristically choose to live with others... Aristotle also means that we have a deeper need to be part of a political community within which we experience richer and more complete lives than are available to us either alone or within small family units.

65. See also Stephen Carden, supra note 47 at 81 . Carden comments regarding Dewey and MacIntyre's conception of the self: 
As noted by Alexander and Peñalver: "living within a particular sort of society, a web of particular kinds of social relationships, is a necessary condition for humans to be able to develop the distinctively human capacities that allow us to flourish." ${ }^{66}$ The community does not exist solely as an instrument to advance the aims of the individuals within it. ${ }^{67}$ Instead, the health and flourishing of the community as a whole is itself a matter of direct moral concern. ${ }^{68}$ Furthermore, the cultivation of values can only happen in a functioning society. An individual must be educated so that moral sensibilities, the faculty of reason, and virtuous action can be learned. ${ }^{69}$ It is therefore part of the moral project to see that individuals are shaped properly, in ways that promote values and lead to human flourishing at both the individual and collective levels.

\section{PRACTICAL REASON IN PLURALIST MORAL THEORY}

The last piece of the pluralist puzzle is the Aristotlean notion of "practical reason." Moral pluralism is a-formulaic. The application of values to moral questions

For Dewey, the self is a confluence of activities taken up through its environment, especially its social environment. The self for MacIntyre is not isolated from society either, but immersed within it. It does not choose to engage in society or enter into a contract to accept its laws; rather, he says that the self is born within society and is constituted by recognition of pre-existing social relationships and the formation of new ones. The idea of the self as an independent substance that stands behind activity to control it is not held by either MacIntyre or Dewey; both philosophers agree that such a conception is illusory and damaging to healthy social relationships.

66. Alexander and Peñalver, supra note 2 at 88.

67. Carden concludes that for both MacIntyre and Dewey, "the virtues are constitutive of the good life, both for the individual and for the community, since these are ultimately inseparable." Carden, supra note 47 at 101. See also Alexander, supra note 62 at 761. Alexander writes: "Community is constitutive of human flourishing in a very deep sense; perhaps community even comprises humanity (as that term is used by many understandings."

68. See also Martha Nussbaum, who argues that " $[\mathrm{t}] \mathrm{o}$ the extent that rights are used in defining social justice, we should not grant that a society is just unless the capabilities have been effectively achieved" (emphasis added) and "[t]o secure a capability to a citizen it is not enough to create a sphere of non-interference: the public conception must design the material and institutional environment so that it provides the requisite affirmative support for all the relevant capabilities." See Nussbaum, supra note 49 at 37, 55.

69. Alexander and Peñalver, supra note 2 at 82 note the following:

Human flourishing unfolds over the course of a person's lifetime as, supported by those around her, she gradually acquires the requisite skills and resources for living well. The virtues necessary for flourishing are not genetically endowed talents. They are dispositions that one acquires over time through careful cultivation, nurturing, support from families, friends, and communities. 
cannot be reduced to a simple rule or set of rules that will resolve all potential cases. As Stephen Carden explains in his analysis of MacIntyre and Dewey, this irreducibility

runs counter to many modern ethical theories, whether classified as deontological or consequentialist, which begin from a focus on the individual and tend to emphasize theory over practice. Not so for MacIntyre and Dewey, who begin by focusing on organized community activities in the pursuit of common goods and who seek the ground for morality in human practices rather than in universal principles of thought. ${ }^{70}$

The identification of values and their proper application involves a complex process of reasoning that attempts to balance, reconcile, and promote relevant values in a particular context. The goal is not to identify one basic principle, but "to identify a framework for describing human flourishing that, as Martha Nussbaum puts it, 'allows for a great deal of latitude for diversity, but one that also sets up some general benchmarks' for evaluating the practices that prevail within a given society as either conducive to or inconsistent with the achievement of the well-lived life." ${ }^{71}$ While there may be certain regularities that can be expressed as general rules of thumb, ${ }^{72}$ there is no expectation that broad rules of moral conduct can be applied mechanically across a wide variety of situations.

\section{B. APPLICATION TO CONDOMINIUM}

Each of these three approaches to property theory interprets and understands condominium differently. Indeed, the very concept of condominium is problematic for the utilitarian view. Utilitarianism is generally uncomfortable with any institution that relies on democratic means to determine, allocate, and define individual entitlements. ${ }^{73}$ This is because, according to utilitarian theory, whatever legal rule or structure maximizes aggregate utility is what should be

70. Carden, supra note 47 at 57.

71. Alexander \& Peñalver, supra note 2 at 88-89, quoting Martha Nussbaum, Women and Human Development (New York: Cambridge University Press, 2000) at 51.

72. Gregory S Alexander argues that there are "multiple ways to reconcile support of rules, or at least rule-like norms, with a relatively robust conception of the social-obligation norm" in his particular version of pluralist property theory in the property law context. See Gregory S Alexander, "Reply: The Complex Core of Property" (2008-2009) 94 Cornell L Rev 1063 at 1064 . See also Hanoch Dagan, who shows how a pluralist view of property could be used to justify a version of the numerus clausus principle despite the lack of a unitary underlying moral formula. See Dagan, supra note 51 at 31-35.

73. Richard Posner, "The Economic Approach to Law" in The Economic Structure of the Law: The Collected Economic Essays of Richard A Posner vol 1 (Cheltenham: Edward Elgar Publishing, 2000) 35 at 45. Posner's essay exemplifies this skepticism in the following passage: 
adopted. Coercive government mechanisms should be limited to those situations in which restricting the ability of individuals to bargain freely over their rights and duties will somehow increase overall utility. Classic examples involve market failures caused by high transaction costs or lack of access to information. ${ }^{74}$ The utilitarian perspective, particularly as it is used in law and economics, leads to the view from public choice theory ${ }^{75}$ that a coercive regulatory process governed through voting procedures provides opportunities for members of the group to enact measures strategically to enhance their personal welfare while lowering the

Were the legal system systematically and effectively designed to maximize economic efficiency, the role of normative economic analysis would be very small. In fact what one observes is areas of the law that seem to have a powerful and consistent economic logic - for example, most common-law fields - and others that seem quite perverse from an economic standpoint - in particular, many statutory fields... So long as there remain important areas of the legal system that are not organized in accordance with the requirements of efficiency, the economist can play an important role in suggesting changes designed to increase the efficiency of the system.

This passage prefers law that is made by a single expert, such as a judge or an economist, over the "perverse" economic logic often found in statutes passed by a democratic body. However, Posner does add the caveat that "[o]f course, it is not for the economist qua economist, to say whether efficiency should override other values in the event of a conflict." (Ibid).

74. In more technical terms, classic law and economics starts with the understanding in microeconomic theory that a completely open and unregulated market will lead automatically to an equilibrium that is fully utility-maximizing. The role of government is thus to secure a completely free market through clear rules of ownership. Governmental intervention in the market itself is then justified primarily when there is "market failure" because the free market mechanism breaks down due to externalities or high transaction costs. See e.g. Robert Cooter \& Thomas Ulen, Law and Economics, 3d ed (New York: Addison Wesley Longman, 2000) at 39-43.

75. James M Buchanan \& Gordon Tullock, The Calculus of Consent: Logical Foundations of Constitutional Democracy (Ann Arbour: University of Michigan Press, 1962). The publication of this book introduced public choice theory. In Encyclopedia of Governance, S M Amadae notes that public choice theory attempts to use economic analysis to understand the behaviour of collective decision-making bodies, and "incorporates the impossibility theorem, holding that if one starts with individuals' preferences, it is impossible to achieve any collective expression of the public good or public interest." See S M Amadae, "Public choice theory" in Mark Bevir, ed, Encyclopedia of Governance (Thousand Oaks, CA: SAGE Publications, 2007) at 765. 
aggregate utility of the group overall. ${ }^{76}$ Utilitarians also tend to be skeptical about the costs of democratic mechanisms as a whole, maintaining that at small scales such as the condominium, such costs outweigh any possible utility gains from the resulting decisions. ${ }^{77}$

The deontological approach fares better for condominium than the utilitarian, at least as a description of existing condominium law. In particular, two ideas that flow from deontological theories work well with condominium: a contractarian approach to rights and duties within the condominium complex, and a rigid approach to the substantive property rights of condo unit owners. ${ }^{78}$

The contractarian aspect arises particularly in the formation of the condominium and the setting of initial responsibilities and entitlements on the purchase of a unit. A decision to purchase a condominium unit can be seen as a decision to enter into a multilateral contract with the other unit owners in the complex. The rights and duties that accompany the purchase then flow from what the purchaser theoretically agreed to in the declaration. Courts and legislatures that adopt this approach favour laws that make changes to the declaration difficult. They also consider the rights and duties of the owners to flow primarily from the declaration, and the resolution of disputes to centre on interpreting the owners' original agreement.

To complement the contractarian analysis, deontological approaches resort to substantive ideas about property rights. According to these approaches, courts and legislatures can import rules governing other forms of property directly into the condominium context without further analysis. Any adjustments to property

76. Henry Hansmann, "Condominium and Cooperative Housing: Transactional Efficiency, Tax Subsidies, and Tenure Choice" (1991) 20:1 J Leg Stud 25 at 34. Noting that the interests of unit owners may diverged, Hansmann observes that:

As a consequence, there will be substantial room for outcomes that do not maximize the aggregate surplus of the occupants. This might occur, for example, when the preferences of the median member are different from those of the mean, or when an unrepresentative coalition achieves dominance in collective decision because their opportunity cost of time is low or because they are otherwise strategically positioned to dominate the decision-making process.

77. Hansmann, supra note 77 at 34-36.

78. For commentators focusing on protection of purchaser expectations, see Patrick A Randolph Jr, "Changing the Rules: Should Courts Limit the Power of Common Interest Communities to Alter Unit Owners' Privileges in the Face of Vested Expectations" (1997-1998) 38:4 Santa Clara L Rev 1081. See also Terrell R Lee, "In Search of the Middle Ground: Protect the Existing Rights of Prior Purchasers in Common Interest Communities" 111:3 (2006-2007) Penn St L Rev 759. For an approach focusing more on traditional property rights, see Cathy Sherry, "How Indefeasible is Your Strata Title? Unresolved Problems in Strata and Community Title" (2009) 21:2 Bond L Rev 159. 
doctrine that might help to accommodate the particularities of condominium should be done sparingly, if at all, and only to the extent necessary to protect property rights. On this view, appeals to the needs of a community or to maximizing aggregate welfare are irrelevant.

Pluralist moral theory works differently from utilitarian and deontological approaches. Where the latter two attempt to provide strict rules or formulae to determine the "best" or "correct" decision in any given case, the pluralist approach provides an overall framework for moral discussion. Rather than privileging any particular value, rule, or metric, pluralist moral theory expects that there will be multiple, incommensurable values at play in any given moral situation, and that the best moral decision (if there is one) will be the one that reconciles the various interests. The theory will also consider the interests of both individuals and the community as deserving moral weight.

In the context of condominium, pluralist moral theory anticipates a careful and complex weighing, balancing, and reconciling of the interests of individual unit holders, the condominium complex as a whole, and possibly of sub-groups within the condominium. While such a theory could value utility, contractual freedom and obligation, and the potential wisdom to be found in traditional property concepts, it would not be confined to such considerations. Additional values such as community harmony, adaptation to changes over time, collective purposes and intentions, and personhood considerations have a role to play.

Moreover, pluralist moral theory would support a weaker standard of judicial review for condominium corporation decisions than either deontological or utilitarian theories. Under the pluralist model, enacting a new rule or resolving a dispute engages a complex process of reconciling disparate values rather than seeking the one "correct" solution. The deliberative, democratic, and community-based process of discussion and voting, when it works well, is conducive to this process. It is not seen as a game that individuals attempt to rig in their favour, or a forum through which the mob can trample on the entrenched rights of others. Instead, the democratic process can be understood within pluralist theory as a good way to take a "first crack" at resolving issues by taking the interests and needs of all interested parties into account through voting and dialogue. The courts need only intervene when the system breaks 
down and some important value or perspective is sidelined or overpowered by the majority ${ }^{79}$

\section{A MORAL THEORETIC ANALYSIS OF CONDOMINIUM DISPUTES}

With the foregoing analysis of the condominium form and its relationship to moral theory in mind, it is now useful to review specific issues and cases. Condominium disputes bring out the differences among the three approaches in sharp detail. In this Part, I review several situations in which Canadian courts and legislators have grappled with property issues in condominium, in contexts that highlight and further illuminate these differences: the availability of the oppression remedy, the right to sue in relation to common property, restrictions on leasing, and dissolution of condominium.

\section{A. COMMON PROPERTY AND THE OPPRESSION REMEDY}

Condominium property includes "common property," areas that are held and maintained in common by all unit owners through the condominium corporation. Usually the common property will include exterior structural elements as well as grounds, hallways, and common facilities. The design of such elements can have a major effect on both the common areas and individual units within the condo. Often, these features have different impacts on different unit owners. In theory, the individual purchase price of a condominium lot should reflect the advantages or disadvantages of that particular lot. If that is the case, then any difference between lots should be of no particular concern on either deontological grounds that the purchaser agreed to the bargain or utilitarian grounds that the purchase was economically efficient. However, the situation is often more complicated due to the close-quarters living in many condominium complexes, the lack of full

79. Some attempts have been made to address collective property forms such as condominium in "mixed" terms, combining utilitarian, deontological, and other considerations, without explicitly adopting a "pluralist" or "value ethics" label. See Hanoch Dagan \& Michael A Heller, "The Liberal Commons" (2001) 110:4 Yale LJ 549 (referring throughout to both "economic and social gains" from collective ownership); Amnon Levahi, "Mixing Property" (2008) 38:1 Seton Hall L Rev 137 at 141-42 (explicitly avoiding a "single normative agenda (such as promotion of efficiency, liberty, or equity)"). Both of these articles focus on the structural elements of collective property ownership and consider moral or ethical justifications piecemeal. Whether these approaches could be considered pluralist, or simply pragmatic, is question for further research and debate. 
fore-knowledge on the part of the buyers, the possibility of mistakes, and the fact that condominium complexes are constantly changing.

Sterloff v Strata Plan VR 2613 involved a dispute over the use of parking garage doors. The complex was mixed-use commercial/residential with a large underground parking area accessible through doors from the east or west. The units immediately above the east door were residential; the units immediately above the west door were all commercial, with residential units above the commercial units. Both doors were industrial-grade parking garage doors that were not intended for use in residences.

Sterloff, an owner of one of the east units, complained about the noise from the door, particularly at night. The door had been out of service when he purchased his unit, so he was surprised by the noise when the door was repaired. Sterloff requested the strata corporation to replace the door with a lighter, residential door, at a cost of at least $\$ 12,500$. The corporation refused, and instead made some minor structural adjustments and restricted use of the east door to prevent entering (but not leaving) the parking lot through it at night. These steps reduced but did not eliminate the noise, and caused increased use of the west door, which led to complaints from the residents above that door.

The court rejected Sterloff's claim that the corporation had failed to meet its duty to repair and maintain the common areas. Instead, the court characterized the issue as a dispute over how to meet that obligation, and held that the proper forum for resolving the dispute was the democratic condominium process, stating:

Pursuant to its bylaws, the strata corporation must control, manage and administer the common property for the benefit of all owners. It seems to me that in carrying out that mandate, the corporation, among other things, must endeavour to accomplish the greatest good for the greatest number.

It seems to me that if the court is to become involved in the particulars of how that obligation is to be fulfilled, then rights and privileges of other members of the corporation may be affected, and accordingly, each member of the corporation should be a party to the proceeding. In my view, the particulars of the method of performance of the obligation are more appropriately defined in a meeting of the corporation, not on an application for a mandatory injunction. ${ }^{80}$

The court's statement that the corporation "must endeavour to accomplish the greatest good for the greatest number" appears on the surface to be a utilitarian approach. However, the judge never considered the costs and benefits of different

80. Sterloff, supra note 81 at 11-12. 
garage door renovation schemes as part of an effort to achieve the greatest overall aggregate benefit. Instead, the court deferred to the decision of the condominium corporation and its democratic process. Such an approach has the greatest affinity with pluralist moral theory.

The scope and meaning of the "greatest good for the greatest number" test from Sterloff was addressed in detail by both the concurring and dissenting opinions in Dollan v The Owners, Strata Plan BCS $1589 .{ }^{81}$ This case is particularly interesting because the judgment of the trial court and those of the concurring and dissenting judges on the Court of Appeal provide clear examples of the utilitarian, deontological, and pluralist approaches. ${ }^{82}$

Dollan arose from a dispute regarding windows in a new complex. The marketing materials for the complex showed a bank of " 01 " units with windows overlooking Vancouver's False Creek. However, those windows also overlooked the windows of the " 02 " units in the complex, situated below the " 01 " units. During construction, the developer changed the windows in the " 01 " units to an opaque "spandrel" style. When the purchasers of the " 01 " units took possession, they sought approval from the condominium corporation to change the windows to clear glass.

Renovations to the exterior windows were a "significant change" to a common area of the condominium, and thus required the approval of a three-quarters majority of the units in the complex. ${ }^{83}$ A large majority voted against the change-19 in favour and 54 against-so two of the "01" unit owners sued the strata corporation, claiming that the decision was "significantly unfair." 84

The trial judge, adopting a utilitarian approach, agreed with the " 01 " unit holders. Citing the "greatest good for the greatest number" passage from Sterloff, the court held that the strata had a duty to make a decision reflecting a proper cost/benefit analysis. In the current situation, the " 01 " owners had been deprived of their view of False Creek to provide greater privacy for the "02" owners. However, the privacy of the " 02 " owners could be protected simply by installing blinds. Thus, the overall "cost" of keeping the status quo was greater than the overall "cost" of converting the windows to clear glass. The strata corporation was thus required to make the change. ${ }^{85}$

81. 2012 BCCA 44 at paras 33-34, 56, 346 DLR (4th) 630, Smith JA, dissenting [Dollan].

82. The second concurring court of appeal decision did not engage in a detailed analysis, so it is impossible to discern which approach was being taken.

83. STA, supra note 20 , s 71.

84. Ibid, s 164.

85. Dollan v Strata Plan BCS 1589, 2011 BCSC 570, 201 ACWS (3d) 836. 
On appeal, the BC Court of Appeal affirmed the trial judge's decision. Justices Garson and Hall wrote separate reasons dismissing the appeal, while Justice Smith wrote a dissenting opinion. The two concurring opinions and the dissent rejected the application of the "greatest good for the greatest number" test as the appropriate test for measuring significant unfairness. The first concurring opinion adopted the corporate law test for shareholder oppression. This test focuses on the "reasonable expectations" of the aggrieved party and asks whether the defending party violated those reasonable expectations by action that was significantly unfair. ${ }^{86}$ Based on the marketing materials, the first concurring judge held that the " 01 " unit purchasers had a reasonable expectation of clear windows overlooking False Creek. Thus, it was significantly unfair for the "02" unit owners to use their majority voting rights to thwart the " 01 " unit holders' expectations. Presumably, this view of False Creek was reflected in the unit purchase price, and so the " 02 " unit holders were depriving the " 01 " owners of a property right for which they paid. In the concurring judge's opinion, the strata could not block this property right through the democratic process.

The dissenting judge took a pluralist approach, holding that the focus of the analysis should not be on the reasonable expectations of the " 01 " unit holders, but on reconciling the interests in the strata as a going concern through the democratic process. The issue of the " 01 " unit holders was properly a dispute between those owners and the developer. As the dissent explained:

In declining the respondents' request, the strata corporation chose to maintain the status quo of the building design. It was under no obligation to remedy the developer's defect; it was only obliged to weigh the competing interests of all affected owners, including concerns about views, privacy, and the exterior appearance of the building, and to make a decision that was not significantly unfair to the respondents. That obligation was met, in my view, by putting the respondents' request before all the owners for a $3 / 4$ vote and then giving effect to the outcome of that vote. ${ }^{87}$

This passage displays two common themes of pluralist approaches: the need to weigh and consider multiple values and interests, and deference to the democratic process. Effectively, the dissent refused to convert the contractual expectations of the " 01 " unit purchasers into an in rem property right enforceable against the world, and instead placed a priority on the need for balancing and community integrity in a condominium development.

The first concurring opinion in Dollan takes a deontological approach, while the dissenting opinion takes a pluralist approach. A second concurring

86. Dollan, supra note 83 at para 30.

87. Ibid at para 64 . 
opinion held for the " 01 " owners without providing a detailed justification. The precedential value of Dollan is thus uncertain. The first concurring opinion makes several dramatic innovations by applying the corporate shareholder oppression test and elevating the status of the purchaser's expectations to in rem property rights. It remains to be seen whether later cases will adopt these innovations.

Unlike BC, Ontario's legislation specifically authorizes an "owner, a corporation, a declarant or a mortgagee of a unit owner" to bring an action for conduct that "is or threatens to be oppressive or unfairly prejudicial to the applicant or unfairly disregards the interests of the applicant." ${ }^{88}$ This oppression remedy is separate from the provisions permitting a party to bring an action to strike down a condominium rule or bylaw for being unreasonable. In McKinstry $v$ York Condominium Corporation No $472,{ }^{89}$ the Ontario Superior Court of Justice held that this provision incorporated the shareholder oppression remedy from corporate law, stating:

Stakeholders may apply to protect their legitimate expectations from conduct that is unlawful or without authority, and even from conduct that may be technically authorized and ostensibly legal. The only prerequisite to the court's jurisdiction to fashion a remedy is that the conduct must be or threaten to be oppressive or unfairly prejudicial to the applicant, or unfairly disregard the interests of the applicant.... It must be remembered that the section protects legitimate expectations and not individual wish lists, and that the court must balance the objectively reasonable expectations of the owner with the condominium board's ability to exercise judgment and secure the safety, security and welfare of all owners and the condominium's property and assets. ${ }^{90}$

The court's description of the oppression remedy in McKinstry appears to be more flexible than that described in Dollan. While the Ontario court acknowledged that the oppression remedy is based on protecting legitimate expectations, it also specified that those expectations must be balanced against the corporation's interest in the welfare and governance of the condominium. The court held that the owners of a unit who had been blocked from unit renovations were not entitled to an oppression remedy, even though they were halfway through the renovations when the decision was made, had received the building manager's assent to the renovations, and had relied on the fact that interior walls were not specified in the declaration as an indication that interior renovations would normally be allowed. The court found that the interests of the

88. Condominium Act, supra note 14, s 135.

89. (2003), 68 OR (3d) 577, 15 RPR (4th) 181 (Sup Ct J).

90. Ibid at para 33 . 
collective in noise control between units, and the fact that the renovations would put the owner's living room beneath the bedroom of the unit above supported the corporation's decision.

McKinstry has been frequently cited by the Ontario courts in oppression cases. ${ }^{91}$ In Metropolitan Toronto Condominium Corporation No $1272 v$ Beach Development (Phase II) Corporation, the Ontario Court of Appeal confirmed that the section 135 remedy is "similar" to the oppression remedy from corporate law, but did not analyze the provision in detail. ${ }^{92}$ It remains to be seen whether the Ontario courts will interpret the oppression remedy in the strict, deontological fashion applied by the concurring opinion in Dollan, or whether they will take a more flexible, pluralist approach as suggested by McKinstry.

\section{B. RIGHTS TO SUE OVER COMMON PROPERTY}

Disputes have also arisen over whether individual owners have a right to bring legal action with regard to common property. Recent decisions from Ontario and $\mathrm{BC}$ exhibit a tendency towards a deontological approach when dealing with the right of an individual unit owner to seek such legal redress.

The issue first arose in BC in Hamilton v Ball, a "leaky condo" case in which a group of owners sued another group of owners in the same complex. The first group claimed that the second group had engaged in improper conduct in attempting to arrange for repairs and renovation of the building. The plaintiffs originally attempted to bring a lawsuit in the name of the strata corporation itself, but they were unable to obtain a three-quarter membership vote to approve the action as required under section 171 of the $A c t .{ }^{93}$ Instead, the plaintiffs commenced an action as co-owners of the common areas in the strata, seeking compensation for the damages that the second group of owners had caused to their individual interests in that common property.

The defendants applied to have the action dismissed on the grounds that section 171 provided the only vehicle for bringing an action in respect of the strata's common property. The chambers judge agreed:

[T] he entire scheme of the Strata Property Act is based on the fact that strata properties involve collective as well as individual rights...

91. See e.g. Durham Condominium Corporation No 90 v Moore, 2010 ONSC 5301, 192 ACWS (3d) 1371; 1240233 Ontario Inc v York Region Condominium Corporation \#852, [2009] 57 BLR (4th) 88, 2009 CanLII 1.

92. 2011 ONCA 667, 208 ACWS (3d) 211 (where the Court of Appeal upheld the lower court's decision denying a finding of oppression in that case).

93. SPA, supra note 14, s 171(2). 
It must be assumed, as the legislature has assumed, that reasonable people protecting their own interests and acting collectively are in the best position to make a decision as to whether or not a certain course of action is warranted given the risks and potential benefits of that course of action. In this case the plaintiffs having been unable to persuade their fellow owners to pursue this course of action against some of their former or present fellow owners must abide, in my view, by the decision made. ${ }^{94}$

In this view, the role of section 171 is to reconcile collective and individual interests. The strata is the representative of the collective interests, and the common property is part of those collective interests. An individual owner can influence the collective decision-making process through voting and other political means, but cannot unilaterally take charge of an issue affecting the whole complex by commencing litigation. The judge also cited an earlier case that applied the rule in Foss $v$ Harbottle ${ }^{95}$ to strata corporations, perceiving individual units owners as legally separate from the strata as a whole. ${ }^{96}$

The BC Court of Appeal disagreed. Noting that the common property in a strata is owned in common by the individual owners, not by the strata corporation, the court concluded that Foss $v$ Harbottle was inapplicable. ${ }^{97}$ Further, the court held that even though collective ownership of common areas is "a type of property unknown to the common law," it nevertheless carries with it the individual right to sue for damage to the common property "as a common law incident of the ownership of property." ${ }^{\prime 8}$ Only very clear language in the SPA could remove such a "common law incident." On this standard, section 171 did not displace the individual right to sue, but simply added the possibility of using the strata corporation as a representative body for the individual owners' interests.

Different concerns motivated each of these decisions. The chambers judge was concerned with the collective resolution of contentious issues within the corporation, and saw the three-quarter voting rule as a means to promote harmony within the community by blocking divisive court action without the support of a supermajority of owners. The BC Court of Appeal focused on the "traditional" entitlement of individual owners without considering collective well-being and the particular context of condominium ownership.

94. Hamilton, supra note 95 at paras 25-26.

95. (1843), 67 ER 189, 2 Hare 461 (establishing that a corporate shareholder cannot sue individually for a wrong done to the corporation).

96. Ang v Spectra Management Services Ltd, 2002 BCSC 1544, 117 ACWS (3d) 830.

97. Hamilton, supra note 95 at para 26.

98. Ibid at para 27. 
This case highlights the tension in condominium cases between "traditional" rights of property and the "new" property arrangements in condominium. The trial judge adopted a remedial and contextual approach to interpreting the rights in a condominium, which are at root creations of a statutory scheme. This approach resonates with pluralist moral theory because it attempts to balance the various interests at play in a condominium complex and considers the needs of the community as a whole. For its part, the BC Court of Appeal adopted a mechanical approach, using property concepts without tailoring them to condominium. This approach resonates with deontological property theory because it focuses on the expectations that parties bring to a conflict grounded in property or contractual norms, and emphasizes the owner's rights—often at the expense of collective interests.

The Ontario Court of Appeal came to a more nuanced conclusion in 1420041 Ontario Inc $v 1$ King West Inc. ${ }^{99}$ In this case, a company pre-purchased several commercial units in a condominium complex and obtained commitments from the developer to alter the design specifications of the individual units and some of the adjoining common areas as part of the purchase agreement. When the developer failed to meet those commitments, the company sued for specific performance. The developer claimed that the unit owner could not bring an individual claim relating to the common areas, citing section 23 of the Condominium Act, ${ }^{100}$ which authorizes a condominium corporation to bring legal proceedings on behalf of the condominium owners (although without requiring a three-quarter membership vote to authorize the action as in BC).

The Court of Appeal found for the unit owner, though on narrower grounds than those used by the $\mathrm{BC}$ court in Hamilton:

What s. 23 is designed to do, in my opinion, is to empower a condominium corporation to bring an action where there is a "common" condominium issue to be addressed-where, as Rosenberg J.A. put it in Wellington [at p. 19 O.R.], "the real injury is to the owners as a group rather than to any individual" (emphasis added). Such a remedy, broad as it is, is not inconsistent with the right of an individual unit owner to pursue contractual or other claims that are unique to the owner's unit, including those touching on common elements that immediately pertain to the unit and that do not concern the owners as a group. ${ }^{101}$

On the surface, this decision resembles the BC Court of Appeal's holding in Hamilton. The court found that the provision allowing a condominium

99. 2012 ONCA 249, 349 DLR (4th) 97 [1 King West].

100. Supra note 14, s 23.

101. 1 King West, supra note 102 at para 21. 
corporation to sue regarding the common areas did not prevent the individual owner from bringing a similar action. However, unlike in Hamilton, the court considered the fact that the common elements at issue "immediately pertained" to the individual units and the owner was suing for specific performance rather than damages. It left the door open for a future case to decide whether a claim can be brought by an individual owner if "the real injury is to the owners as a group." 102

The issue of an individual owner's right to sue has significant implications for the nature of property in a condominium. Curtailing the right of an individual owner to sue regarding common property, either absolutely or when the "real injury is to the owners as a group," promotes communal stewardship and decision-making for the common property over the piecemeal interests of individual owners. It places responsibility for the common areas at the community level and recognizes that taking legal action has an impact on the social and financial integrity of the entire complex. Such an approach is readily justified under a pluralist theory, which demands consideration of both individual and community interests in determining property rights. It struggles, however, under a deontological approach, as it empowers the collective to interfere with the ability of individual owners to advance and protect their property rights.

\section{LEASING RESTRICTIONS}

The ability to lease condominium property to third parties has often been construed by the courts as a traditional incident of property ownership. At the same time, there has been a push by many condominium owners to restrict leasing of units. Lessors are often seen as less invested in the community of the condominium and responsible for additional costs, while investor-owners are portrayed as being distant from the complex and having interests at odds with those of owner-occupiers. ${ }^{103}$ Earlier court decisions protecting the right to lease have been gradually giving way to legislation and court decisions that permit leasing restrictions.

102. Ibid.

103. See Randy Lippert, "Governing Condominiums and Renters with Legal Knowledge Flows and External Institutions” (2012) 34:3 Law \& Pol'y 263 at 268. Randy Lippert summarizes this widely-held as follows:

By their mere presence renters call into doubt the condominium ideal, which is premised on owners sharing and governing common spaces together in a stable 'community.' Renters are a discursive affront to the possibility of the condominium due to their assumed disregard for the nobility of home ownership and lack of care for property. 
The classic case in Ontario is Re Peel Condominium Corporation No. 11 and Caroe, ${ }^{104}$ where the condominium's declaration restricted occupancy of each unit to the owner's family. However, several unit owners leased units to non-family members. The condominium board attempted to evict the tenants and obtain an order prohibiting the owners from leasing the units. The court held that "[o]ne of the fundamental incidents of ownership is the right to alienate the property that one owns," ${ }^{105}$ tracing the origin of this idea to the Statute Quia Emptores, an English law passed in $1290 .{ }^{106}$ The Condominium Act provided that a declaration could contain "provisions respecting the occupation and use of the units and common elements." 107 However, the court determined that this language was not clear enough to permit a declaration to contain restrictions on leasing an individual unit.

It is unclear why the court did not refer to another subsection in the Condominium Act that deals specifically with restrictions on leasing. Subsection $7(2)$ (c) provides that the declaration may contain "conditions or restrictions with respect to gifts, leases and sales of the units and common interests." ${ }^{108}$ In any event, the Court's narrow interpretation highlights the difference between a deontological view and a pluralist one. On a rights-based view of property, restrictions on alienation or leasing are difficult to justify because they restrict the power and freedom of property owners. Only a strong contractarian view could support such restrictions. However, the court in Caroe rejected this view, holding that the declaration of a condominium complex could not validly create restrictions on leasing.

A pluralist view of property allows greater scope for leasing restrictions without mandating a single, blanket rule. From one perspective, restrictions on leasing could contribute to community well-being by promoting residential stability and a sense of investment in the community. ${ }^{109}$ Restrictions could also relieve a condominium corporation from involving absentee investor-owners when making decisions. However, restricting rentals reduces the options of individual owners. Allowing rentals could also contribute to the community by bringing in people whose socio-economic status makes them unable to purchase a unit. On a pluralist approach, these various factors could be balanced in the

104. (1974), 4 OR (2d) 543, 48 DLR (3d) 503 (SC).

105. Ibid.

106. $18 \mathrm{Edw} \mathrm{I}, \mathrm{c} 1$.

107. Condominium Act, RSO 1970, c 77, s 3(2)(c).

108. Condominium Act, supra note 14, s 7(4)(c).

109. See Lippert, supra note 106. Lippert discusses how negative attitudes towards condominium renters has turned them into a type of "other" in condominium governance. 
context of a particular complex, and a solution could be tailored to that complex. This approach would avoid the one-size-fits-all solution suggested by Caroe.

More recently, courts in Ontario have been moving towards such a nuanced, context-sensitive approach regarding restrictions on short-term leasing. In Skyline Executive Properties Inc v Metro Toronto Condominium Corporation No 1280, a condominium declaration restricted occupancy of each unit to a single family. ${ }^{110}$ The condominium corporation also enacted rules prohibiting the leasing of units for an initial period of less than one year. Skyline purchased several units in the complex, started using them as part of its short-term hotel leasing business, and brought a court action to declare the leasing restrictions invalid. Breaking from Caroe, the court did not analyze Skyline's application in terms of the traditional incidents of ownership or fundamental rights of alienation. Instead, the court considered whether the restrictions on leasing conformed with the provision in the declaration that the units were restricted to single-family residential use, and deferred to the corporation's role in "balancing the private and communal interests of the unit holders." 111 The court upheld the leasing restrictions.

A similar situation occurred in Metropolitan Toronto Condominium Corporation No 1170 v Zeidan, where an individual purchased several units in a condominium and then leased those units to a hotel company for use as short-term rentals. ${ }^{112}$ The condominium declaration specified that nearly all units in the complex, including all those at issue in the case, were to be used as "residential dwelling units." The condominium corporation enacted a rule prohibiting any lease for fewer than three months. The individual lessor challenged this rule. Again, the court did not analyze the issue in terms of the traditional rights of property. Instead it considered whether the rule was validly enacted under the Condominium Act, which requires that condominium rules must either "promote the safety, security or welfare of the owners and of the property and assets of the corporation" 113 or "prevent unreasonable interference with the use and enjoyment of the common elements, the units or the assets of the corporation." 114 Rules must also be "reasonable" and consistent with the Act, declaration, and bylaws. ${ }^{15}$ The court held that the condominium corporation had demonstrated that the disruption caused by short-term tenants justified

110. 253 DLR (4th) 656, [2001] OJ No 3512 (QL) (Sup Ct) [Skyline].

111. Skyline, supra note 113 at para 16.

112. (2001), 106 ACWS (3d) 760, 43 RPR (3d) 78 (Ont Sup Ct) [Zeidan].

113. Condominium Act, supra note 14, s 58(1)(a).

114. Ibid, s 58(1)(b).

115. Ibid, s 58(2). 
taking action to restrict such leasing and that the condominium corporation was entitled to "considerable deference" in determining the appropriate rules for dealing with such disruptions. ${ }^{116}$ Again, the court upheld the leasing restrictions.

Both of these decisions on short-term leasing follow a pluralist approach. Rather than confining the analysis to individual property rights, both courts considered the character of the developments, the limited nature of leasing restrictions, and evidence regarding the disruption, increased costs, and altered nature of the community caused by the short-term rentals. The court also gave deference to the condominium corporation and the results of the democratic process. Rather than seeing these restrictions as incursions on the narrow property rights of individual owners, the courts saw them as enhancing the value of the complex and enabling the owners to create the residential community contemplated in the declarations.

In British Columbia, the courts were initially skeptical of restrictions on leasing. Earlier versions of the legislation permitted a strata corporation to limit the number of units in the complex that could be leased, ${ }^{117}$ but the courts held that the use of the word "limit" precluded an absolute restriction on leasing. ${ }^{118}$ The courts in these cases shared the concerns in Caroe: The condominium statute should be strictly interpreted to favour "traditional" rights of property.

However, under the new Strata Property Act (1998) the BC legislature provided that a strata can prohibit all leasing of residential units, ${ }^{119}$ subject to several narrow exemptions for hardship, ${ }^{120}$ family members, ${ }^{121}$ and existing tenants when a new restriction is passed. ${ }^{122}$ The new regime in $\mathrm{BC}$ rejects the courts' earlier "property rights first" approach. By expressly permitting prohibitions on most leasing activity, the legislature has enabled strata complexes to tailor leasing to their particular needs. Such flexibility corresponds to a pluralist vision of property rights, balancing the interests of individuals and community.

The exemptions are also illustrative. Each identifies a situation where the interests of the individual owner or tenant will generally outweigh the interest of the collective. The exemption for hardship recognizes that, in some circumstances, owners may be forced to rent out their units to make ends meet.

116. Zeidan, supra note 115 at para 44 .

117. Condominium Act, RSBC 1996, c 64, as repealed by SPA, supra note 14, s 294.

118. For a detailed summary of these cases, see Marshall v Strata Plan No NW 2584 (1996), 27 BCLR (3d) 70 at paras 37-44, 64 ACWS (3d) 1070.

119. SPA, supra note 14 , s 141 .

120. Ibid, s 144 .

121. Ibid, s 142 .

122. Ibid, s 143 . 
The exemption is not automatic, but allows an owner to apply for permission to lease. While the corporation "must not unreasonably refuse to grant an exemption," ${ }^{123}$ it may limit its duration. ${ }^{124}$ The need to make an application, the deliberative process it invokes, and the specific provision that the exemption may be temporary suggest that the hardship provision incorporates a pluralist balancing of interests, with the needs of the community and the needs of the individual owner considered together.

The exemption for family members also involves a situation where the interests of individual owners are likely to outweigh the interests of the collective. Here, the exemption is automatic: the strata corporation cannot refuse the rental. ${ }^{125}$ Unlike the hardship exemption, where the balancing of interests is left to the strata corporation (within certain limits), the balancing of interests has been done by the legislature. However, the exemption is narrow and supported by reference to the value of family integrity and harmony. While rentals to third parties are likely to be financially motivated, rentals to family members involve complex dynamics including family stability, intergenerational use of residential property, and continuity of asset ownership. The exemption for family members seems to be motivated not by a rights-based approach to property, but by recognition that residences are often a family asset and that the use of a strata unit within a family should prevail over restrictions enacted by the relative strangers living in the complex.

Finally, the exemption for existing tenants allows an existing lease to continue indefinitely after a strata complex introduces leasing restrictions. ${ }^{126}$ This exemption could be justified either by a deontological approach or a pluralist approach, and is a recognition of the importance of housing security.

\section{CONDO DISSOLUTION}

One area that has led to special challenges in the context of condominium is condominium dissolution. Dissolving a condominium complex currently requires an 80 per cent supermajority vote in Ontario and a unanimous vote in $\mathrm{BC},{ }^{127}$ though recent amendments not yet in force will bring BC into line with

123. SPA, supra note 14, s $144(6)$.

124. Ibid, s $144(5)$.

125. Ibid, s 142(2).

126. SPA, supra note 14 , s $143(2)$.

127. Condominium Act, supra note 14, s 122; SPA, supra note 14, ss 269, $272 \mathrm{ff}$. 
Ontario's eight-tenths supermajority requirement. ${ }^{128}$ Interested parties can also apply to have the condominium dissolved by court order if the applicable voting threshold is not met. Douglas C Harris and Nicole Gilewicz have suggested that the difference between a supermajority requirement and a unanimity requirement for dissolution reflects different conceptions of condominium property. ${ }^{129} \mathrm{On}$ the one hand, a supermajority rule "constructs property to protect its exchange value for the owner as investor" as it protects the right to compensation, but does not provide a veto over the sale. ${ }^{130}$ On the other hand, a unanimity rule "protect[s] the interest itself for the owner, usually as resident or occupant," as it does provide a veto. ${ }^{131}$ The supermajority rule thus resonates with the utilitarian goal of maximizing utility or wealth and permitting coercive transactions to overcome holdouts. The unanimity rule, on the other hand, fits best with a deontological conception that promotes the freedom and rights of the individual. However, both jurisdictions allow unit owners to apply for a court-ordered dissolution of a complex when the voting threshold is not met. This opens the door for courts to take a context-based, pluralist approach to dissolution that balances many factors and considers the interests of both the individual owners and of the collective.

Royal Insurance Co of Canada v Middlesex Condominium Corporation No 173 is particularly instructive. ${ }^{132}$ The case involved a poorly-planned condominium with both residential and commercial units. Royal Insurance took over the vast majority of the units though foreclosure proceedings and proposed a reorganization plan to split the complex into two separate condominiums-one with all the residential units and one with all the commercial units-and to conduct a number of repairs and renovations. Nine of the fifty-one remaining residential owners rejected the plan, insisting on being bought out if the reorganization proceeded.

Royal Insurance applied to dissolve the condominium and to implement its reorganization plan. It relied on section 46 (now section 128) of the Condominium

128. Bill 40, Natural Gas Development Statutes Amendment Act, 4th Sess, 40th Parl, British Columbia, 2015, ss 37-55 (assented to 17 November 2015).

129. Douglas C Harris \& Nicole Gilewicz, "Dissolving Condominium, Private Takings, and the Nature of Property" in B Hoops et al, eds, Context, Criteria, and Consequences of Expropriation (The Hague: Eleven, Forthcoming 2015). On changing conceptions of condominium property generally, see "Douglas C Harris, "Anti-Social Behaviour, Expulsion from Condominium, and the Reconstruction of Ownership" (2016) 54:1 Osgoode Hall LJ 53.

130. Ibid at 41.

131. Ibid.

132. (1998), 37 OR (3d) 139, 155 DLR (4th) 94 (CA) [Royal Insurance]. 
Act, which authorizes the court to dissolve a condominium complex if the termination "would be just and equitable" and to include in the termination order "all provisions that it considers appropriate in the circumstances." By proceeding this way, Royal Insurance attempted to circumvent the general rule that, upon termination of a condominium, the entire property is converted into a tenancy in common.

The trial judge refused to grant the order. On appeal, the majority held that the relief sought by Royal was not authorized by section 46 . The majority's reasoning was grounded in concerns about "forc[ing] the objecting respondents to become unit owners in one of these new condominiums," 133 and in the view that the power to alter individual property rights would require clearer legislative authority than the residual power to make supplementary orders on dissolution found in (then) subsection 46(3).

The dissent took a broader view. It reviewed the underlying interests and concluded that Royal's plan was reasonable, better than the status quo, and had the potential to revitalize the complex:

Because of the fairly recent development of the condominium concept, no body of law has developed around the problems which will inevitably become increasingly frequent and diversified as facts warranting termination arise. With considerable foresight, the legislation has provided the court with a very broad discretion under s. 46(3) to act as it considers appropriate in the wide variety of fact situations which could arise on termination. The order requested in this case is clearly in the interest of all owners, and it would be unfortunate for all if a very small number of dissenters could frustrate the carrying out of a beneficial proposal endorsed by almost all of the unit owners. ${ }^{134}$

Without court approval, Royal Insurance and the forty-three owners who supported the plan had two options: buy out the dissenters, who were likely to attempt to secure greater than fair market value for their units; or apply for a classic dissolution, after which the entire property would be in the hands of the previous owners as tenants in common. The dissenting judge concluded that neither of these alternatives was fair or realistic.

The judges in the majority grounded their decision firmly in deontological concerns. For them, ordering the holdout owners into the restructuring plan would force them to accept a change in their property rights without consent. The majority was not prepared to allow such a change without a clear statutory mandate. Despite the merits of the proposed reorganization, the logic of property

133. Royal Insurance, supra note 135 at 146-47.

134. Ibid at 145-46. 
rights required the court to uphold the ability of the holdout owners to refuse reorganization regardless of the consequences.

By contrast, the dissent looked beyond the bare logic of property to consider what made sense in this particular situation. Considering that the condominium form was a relatively new development that marked a significant change from common law estates, the dissent accepted that the termination provisions allowed broad leeway to fashion remedies that were context-sensitive and not bound to traditional conceptions of property. Despite the fact that the termination order would alter property rights, the dissent would have sanctioned the reorganization plan as being in the best interests of the entire complex.

The dissent in Royal can be understood from either a pluralist or utilitarian perspective. For a utilitarian, this case presented a classic holdout dilemma in which a small minority of interested parties hold up a decision that will likely increase aggregate utility. Requiring the holdouts to conform to the restructuring plan would likely be the most efficient decision. From a pluralist standpoint, the case demonstrates a situation where asserting rights under a traditional property rule was unlikely to promote the overall flourishing of the community. Unless the holdout owners could demonstrate some specific human value protected by withholding consent that countered the interests of the other owners in protecting their investment and revitalizing the complex, the interests of the other individuals and the greater community should have prevailed.

Royal involved an unusual situation. Issues regarding dissolution usually arise when some, but not all, of the owners in a complex want to accept a buy-out offer from a developer. Often, such offers are greater than what could be realized on individual sales of the units. Harris and Gilewicz suggest that these cases pit the "owner as investor" who is interested in realizing the greatest economic benefit of the property, against the "owner as resident" who is interested in protecting the integrity of his or her home and neighbourhood. ${ }^{135}$

Two recent cases from BC present an instructive contrast in this regard: Mowat v Dudas ${ }^{136}$ and McRae v Seymour Village Management, Inc. ${ }^{137}$ These cases involved the rare "common law" condominium, formed not under condominium legislation but through a complex series of covenants and other title restrictions. In practice, the complexes were run similarly to statutory condominium, with common areas managed by a central corporation in which every individual had a membership. The dispute in both cases involved a proposal supported by a group

135. See Harris \& Gilewicz, supra note 132.

136. 2012 BCSC 454, 215 ACWS (3d) 230 [Mowat].

137. 2014 BCSC 714 at para 3, [2014] BCJ No 766 [McRae]. 
of owners to sell the whole complex to a developer for an amount in excess of what could be obtained if each unit was sold individually.

Mowat concerned Cypress Gardens, a complex in North Vancouver with 177 units situated on 9.5 acres. A development company approached the owners of Cypress Gardens with an offer to buy the entire complex for a sum that it claimed was greater than the aggregate market value of the separate units. Some of the owners wished to sell, but a substantial number refused. Those wanting to sell brought an application under the Partition of Property Act for an order forcing the sale of the entire property.

The BC Supreme Court determined that only the owners of 54 of the 177 units wanted the sale-less than one-third of the total. Further, a large number of owners vigorously opposed the sale, and offered many different reasons for their opposition. While the petitioners claimed that the complex was in a state of disrepair and that the owners could not afford the necessary renovations, the respondents claimed that a credible plan was in place to finance and undertake the repairs. Many respondents also questioned whether the proposed sale price was adequate, and wanted to see a democratic resolution to the issue rather than a court-ordered sale. Other owners opposed the sale because of their investment in the community, because they were elderly or disabled and did not want the hassle of moving, because they had small children who would be displaced by a move, or because the amount offered would not enable them to buy replacement housing in North Vancouver close to their schools and workplaces. Additionally, owners with outstanding mortgages argued that they would have to pay heavy mortgage penalties.

The court refused to grant the order for sale. Orders under the Partition of Property Act are discretionary and enable judges to consider a wide range of factors in determining whether an order is just and appropriate under the circumstances. ${ }^{138}$ In its reasons, the court considered a combination of factors, some of which have deontological overtones and some of which are more pluralist. On the deontological side, the court considered that when most of the owners purchased their units, they did not understand the difference between a "common law" condominium and a statutory condominium, and likely expected that dissolution or sale of the entire complex would have to follow a democratic procedure such as the process laid out in the Strata Property Act. ${ }^{139}$ Purchasers

138. Mowat, supra note 140 at paras 141-46.

139. Under the current Act, voluntary cancellation of a strata plan requires unanimous consent from all the owners. See SPA, supra note 14, s 272. 
would have assumed that they were buying a piece of real estate that could not just disappear under a court application by their neighbours. ${ }^{140}$

On the pluralist side, the court considered the many interests of the individuals opposed to the sale. In particular, the court recognized the hardship of breaking up friendship networks, the problem of leaving families in a position where they would have difficulty finding replacement homes, and the special needs of the elderly and disabled people in the complex. Finally, the court noted that well under half of the owners were in favour of the sale, and it seemed unfair to displace the large majority of the owners in the complex against their will.

While there are some deontological concerns in the court's reasoningespecially regarding the expectations of the unit purchaser regarding the means of dissolution - the main thrust of the decision is a pluralist balancing act, considering the many different factors put forward by the parties and seeing the complex not merely as a collection of property rights but as a community with families, elderly people, and people with illnesses and disabilities. In part, this is a function of the Partition of Property Act and the discretionary nature of the remedy it affords. However, under this discretionary power the court may focus on the reasonable expectations of the parties, or on the best way for the owners to secure a financial benefit from their investment. The court chose not to focus on either consideration, and instead considered the individual circumstances of the opposed owners along with their connections to the community in Cypress Gardens and to North Vancouver generally.

McRae provides a useful contrast to Mowat. The case involved a similar application under the Partition of Property Act, brought by owners of units who wanted to sell the complex to a developer for a significant premium above the individual unit value. ${ }^{141}$ The petitioning owners were concerned that the complex was in a state of disrepair and that there was no agreement on raising the funds necessary for renovations. The objecting respondents cited reasons similar to those raised in Mowat: connection to the community, hardship from being forced to move, and concern that similar housing could not be purchased for the price offered by the developer. The principal difference between the Mowat and McRae was that in McRae, over 90 per cent of the owners favoured the sale. This, combined with the deadlock on renovations, enabled the court to distinguish

140. On this point, the court seems to be misguided. There is a mechanism for court-ordered dissolution under the SPA that is similar to an application for partition and sale under the Partition of Property Act, SBC 1998, c 43, s 284.

141. McRae, supra note 141. 
the case from Mowat. ${ }^{142}$ The court found that the large majority of owners who wanted to realize as much as possible on their investments and purchase new homes could not fairly be blocked by the handful who wanted to stay.

It is tempting to see these two cases as representing the two approaches described by Harris and Gilewicz: Mowat protecting the interests of the owners as residents, and McRae protecting the interests of owners as investors. However, a careful reading of the cases reveals that there is more going on here. The main difference between the two cases is the percentage of owners who supported the sale. If the goal were absolute protection of the owners as residents, then the detailed analysis of the individual owners' situations in Mowat would be unnecessary-the mere fact that unanimity could not be achieved should be dispositive. Similarly with McRae, if the goal were simply to promote the investment value of the properties, then the raw percentage of willing owners would not be relevant; rather, the court should have asked simply whether a sale of the whole complex would provide the best return on the owners' investments. By making the percentage of owners who agreed to the sale the main concern, the courts leaned towards a pluralist moral view of property, and in particular, towards deference to the democratic will of the large majority of owners and their vision of the community in the complex.

Perhaps the most informative situation would be a case where there is only a simple majority in favour of a sale, not a super-majority. In such a case, the court would not have an overwhelming mandate from the owners as to whether or not the property should be sold, but rather would be faced with two substantial factions of owners with opposing positions. The factors a court would consider on such an application, and in particular those it would consider to be the most important or relevant, could give even greater insight into whether the courts take a truly pluralist approach.

In both Mowat and McRae, the legislative voting threshold for voluntary dissolution of a condominium was not at issue because both developments were common law condominium. Nonetheless, the courts came to the same result that would obtain under BC's incoming 80 per cent supermajority requirement. ${ }^{143}$ Further, under the new legislation, any voluntary dissolution of a strata with 5 units or more must be approved by court order. The court has discretion to grant or refuse the order and must consider "the best interests of the owners," the probability of significant unfairness to owners and creditors, and

142. Ibid at para 40.

143. Bill 40, supra note 131. 
"significant confusion and uncertainty in the affairs of the strata corporation or of the owners." 144

These amendments were a response to a recent British Columbia Law Institute report that questioned the unanimity requirement, noting that it is "out of step with trends in strata legislation across Canada and elsewhere." 145 The report recommended amending the Strata Title Act to require only an 80 per cent vote, citing fairness to the majority of unit owners as a major concern:

[I]t is possible to question the fairness of requiring unanimous consent of the owners to termination of a strata. Maintaining a unanimous consent requirement holds out the possibility - maybe even the likelihood—that an overwhelming majority of owners will be thwarted by a minority, which may be as small as one owner. ${ }^{146}$

According to the report, this recommendation was "strongly supported by respondents to the consultation paper." ${ }^{147}$ The report also recommended that all voluntary dissolutions be subject to court approval, in part as a means of protecting dissenters against an unfair sale. ${ }^{148}$ It remains to be seen how the courts will interpret the new provisions. They may interpret their discretion narrowly, overturning an 80 per cent vote in favour of dissolution only when there was a flawed process or an egregious case of substantive unfairness against the dissenting owners. However, the language of the statute does require consideration of broad factors such as the best interests of the owners, significant unfairness, and significant confusion and uncertainty in the affairs of the strata. The shift to a supermajority requirement, as well as the need to obtain a discretionary court order, open the possibility of a shift away from a rigid rights-based approach to a more flexible and context-sensitive pluralist approach.

\section{CONCLUSION: JUDICIAL TRENDS AND THE BENEFITS OF A PLURALIST APPROACH}

Condominium creates many challenges. The foregoing review of legislative and judicial solutions to these challenges highlights varying ways to respond. The idea that condominium is a new property form that requires new ways of thinking is a recurring theme. While the logic of property is engaged, especially as regards

144. Ibid, ss 48,52 .

145. British Columbia Law Institute, Report on Terminating a Strata (Vancouver: British Columbia Law Institute, 2015) at 54.

146. Ibid.

147. Ibid at 55 .

148. Ibid at $79 \mathrm{ff}$. 
individual ownership, there are repeated references to the community of owners and to the need for that community to manage the complex and operate through the logic of common interests and democratic governance.

No single theory of property dominates. However, there are several trends. First, utilitarian approaches have not gained much traction. This is hardly surprising. Utilitarian approaches to property rights, especially as interpreted in the law and economics tradition, sit uncomfortably with condominium. The tradition emphasizes free alienability of property and the allocation of resources though the market. By importing ideas of democratic governance into property, condominium destabilizes the content of property rights, reduces the ability of owners to bargain freely, and enables owners to pursue their interests through a coercive regulatory mechanism.

In deciding condominium cases, the courts do not embark on a wealth-maximizing, cost-benefit analysis. Decisions regarding the right to sue individually for damage to common areas are founded on common law property concepts. They do not analyze whether such actions are utility-maximizing ${ }^{149}$ and may consider whether the "real injury" is to an individual owner or to the community without a utility analysis. ${ }^{150}$ In their article on forced sales in condominium, Harris and Gilewicz note that while the results in these cases could be supported by an efficiency analysis, the language of the judicial opinions "suggests there is more at stake in these conflicts than the efficient allocation of property interests" and that the interests of the owners in their homes "were not to be thought of primarily in terms of fungible, transferable objects of value, but rather as a means to secure autonomous and fulfilling lives embedded within community." 151 Similarly, the court decisions on leasing restrictions either prohibit such restrictions on the basis that the right to lease is a traditional incident of property ${ }^{152}$ or defer to the democratic decision making process. ${ }^{153}$ None of the decisions consider utility maximization.

Moreover, one of the major recommendations made by law and economic scholars is absent. Ellickson has proposed a "regulatory takings" rule for condominiums, under which any action that decreases the economic value of a unit, such as a bylaw restriction or a re-designation of exclusive-use common

149. Hamilton, supra note 95; see discussion supra notes 95-101.

150. 1 King West, supra note 102. See discussion supra notes 102-105.

151. Harris \& Gilewicz, supra note 132.

152. See e.g. Peel Condominium Corp v Caroe (1974), 4 OR (2d) 543, 48 DLR (3d) 503 (SC) [Caroe]; see discussion supra notes 107-112.

153. Skyline, supra note 113; Zeidan, supra note 115. See discussion supra notes 113-119. 
property, would give the owner of that unit a claim for compensation. ${ }^{154}$ Such a rule would ensure that any decision produces an increase in overall utility; if it did not, then the cost to compensate the "losing" owners would be high enough to deter the "winning" owners from enacting it. However, there are no provisions in either the $\mathrm{BC}$ or Ontario legislation to require or even permit a "regulatory takings" regime within condominium. In the recent comprehensive reviews of both legislative regimes, there is no mention of a regulatory takings regime. ${ }^{155} \mathrm{It}$ would appear that policy makers, the courts, and the public in general do not consider such a regime to be appropriate for condominium.

Second, there is a gradual trend away from deontological approaches and towards pluralist approaches. This is especially true in the context of leasing restrictions and dissolutions. In the case of leasing restrictions, the strict prohibition originally endorsed in $\operatorname{Caroe}^{156}$ was later modified by a pluralist approach that permits leasing restrictions resulting from reasonable deliberations by the condominium corporation. ${ }^{157}$ In $\mathrm{BC}$, the courts originally resisted restrictions on leasing; however, legislative amendments have clarified that restrictions on leasing are permissible, with a few narrow exceptions for hardship, family members, and existing tenants. ${ }^{158}$

For dissolutions, the older position is represented by Royal Insurance Co of Canada v Middlesex Condominium Corporation No 173, ${ }^{159}$ in which the Ontario Court of Appeal refused an innovative restructuring plan for a condominium on deontological grounds. However, in more recent cases involving offers for sale in "common law" condominium, the courts are coming to a more flexible view, balancing a range of interests and factors in determining whether to grant petitions for dissolution. ${ }^{160}$ Also, as discussed in the previous part, the BC legislature has recently adopted a new dissolution procedure that signals a shift towards a pluralist approach.

However, the courts have resisted pluralist approaches in two settings: determining rights to sue for damage to common areas, and applying the "oppression" remedy. For these situations, the courts agree with commentators

154. Robert Ellickson, "Cities and Homeowners Associations” (1982) 130:6 U Pa L Rev 1519.

155. See discussion supra notes 150-153 and infra notes 182-193.

156. Caroe, supra note 14. See discussion supra notes 107-112.

157. Skyline, supra note 113; Zeidan, supra note 115.

158. See discussion supra notes 122-129.

159. 37 OR (3d) 139, 155 DLR (4th) 94 [Royal Insurance Co]. See discussion supra notes 135-139.

160. Mowat v Dudas, 2012 BCSC 454 and McRae v Seymour Village Management, Inc, 2014 BCSC 714; see discussion supra notes 140-149. 
such as Randolph and Lee who advocate enhancing protection for the expectations of purchasers. ${ }^{161}$ In both Ontario and BC, the courts have interpreted the legislation to allow individual owners to sue for damage to common areas even if they cannot get approval from the strata to bring the suit in its name. ${ }^{162} \mathrm{In}$ Ontario, this may be limited by a judicial caveat that an individual owner may bring a separate suit only where the damage to the common area has a particular impact on their unit. In BC, however, an individual owner or group of owners may unilaterally sue concerning problems with the common property in general. This position is at odds with a pluralist approach, because it allows owners to bypass the democratic process with respect to disputes over the common areas, raising the stakes in a condominium dispute and making harmonious resolutions more difficult.

The oppression remedy resonates with Randolf and Lee's suggestion to protect the expectations of purchasers. While it can be a flexible doctrine, responsive to context and the need to harmonize various interests, the remedy has a deontological flavor because it is based on "reasonable expectations" and designed to block otherwise lawful action taken by a majority. Decisions from Ontario have taken the flexible approach, but the concurring opinion in Dollan in the BC Court of Appeal may be a harbinger of stricter decisions to come.

Third, the cases reveal divisions in attitudes towards condominium. Judicial opinion diverged wildly in Hamilton, Royal, and Dollan. In Hamilton, the trial court held that individual owners could not sue unilaterally regarding the common areas, emphasizing the need to promote collective management. By contrast, the BC Court of Appeal emphasized the traditional rights of property and the need for part owners to bring legal action to protect part interests. In Royal, the majority on appeal emphasized the need to protect entrenched rights of owners on a proposed reorganization, while the dissent showed a willingness to deviate from traditional property doctrine to ensure the viability of the entire complex. And in Dollan, the trial judge, one concurring judge on appeal, and the dissenting judge on appeal all took very different approaches, inspired by utilitarian, deontological, and pluralist perspectives. These different approaches highlight the challenges that condominium raises for property and its underlying philosophical justification.

I now turn to a normative argument that pluralist approaches to condominium lead to better results. This is principally because condominium requires room for democratic action in the shaping of rights and obligations, and

161. Randolph, supra note 79.

162. Hamilton, supra note 95; 1 King West, supra note 102. 
in resolving disputes. The case law reveals that while deontological (and utilitarian) approaches inhibit the ability of condominium corporations or reviewing courts to achieve solutions, pluralist reasoning accommodates the various interests at stake, provides a framework to find creative ways to move forward, and respects the outcome of the democratic process.

Cases where judges have described the implications of the different approaches to one particular situation are especially instructive. In Hamilton $v$ Ball, the trial judge suggested that "the entire scheme of the Strata Property Act is based on the fact that strata properties involve collective as well as individual rights." 163 The judge was concerned about the ability of one faction of unit owners to disrupt a difficult and costly democratic process through litigation. From a deontological perspective, this can look like unfair suppression of the property rights of owners. However, from a pluralist perspective, this restriction encourages democratic resolution of disputes and deters a faction of owners from hijacking the process. Owners opposing court action have property interests in the common areas as well, and if no clear consensus exists for bringing a court action, then the supermajority rule prevents a tiny minority, or even a simple majority, from imposing the cost and acrimony of litigation on the rest. The deontological approach taken by the BC Court of Appeal precludes these important considerations.

The approach taken in 1 King West,${ }^{164}$ may strike a better balance, by requiring that unilateral suits regarding common property be restricted to cases where one owner or group of owners are especially aggrieved by the particular interests in the common areas. This approach gives individuals the power to take action when their unique interests are affected while leaving general matters to be dealt with collectively. Respect for autonomy, privacy, and other values that adhere to individuals are thus reconciled with the values of community cohesion and deliberative decision making.

Similar remarks apply to Royal Insurance Co. ${ }^{165}$ In that case, the majority refused a reorganization plan on the narrow ground that it would alter the property rights of a small minority of owners without their consent. And yet, condominium contemplates precisely that, through the democratic process of amending the declaration and bylaws. While not all property rights in a condominium need to be subject to democratic will, some certainly do. To confine the question in a case like Royal Insurance Co to "Does the proposed change alter property rights

163. Hamilton, supra note 95 at para 25.

164. Supra note 155.

165. Supra note 164. 
without consent?" limits the investigation and ignores the democratic aspect of condominium property. The better question is, "Does the proposed change represent a balanced and measured solution that adequately serves the interests of the individual unit holders and the condominium as collective?"

Disputes such as these suggest how a pluralist approach ought to inform the enactment and interpretation of condominium legislation. From this perspective, the onus on the parties to a condominium dispute would be to name and justify the values served by the institution of the condominium, and then to explain why their proposed course of action best reconciles those values. In a situation such as Royal, the insurance company and the majority owners can point to community harmony, commercial viability, and preservation of economic value to advance their claim that the Condominium Act should be interpreted to permit the restructuring. The minority owners can point to the values served by their position: stability, maintenance of expectations, and autonomy. The court can then explicitly consider these values and make a decision that achieves a just result under the circumstances.

The pluralist approach could also impact the way expectations work in property law, and the understanding of what someone "buys into" when they purchase a condominium unit. While condominium could be seen as a mere "community of convenience," the disputes reveal a more complex character. A distinction drawn by Gregory Alexander between "voluntary associations" and "communities" is useful here. ${ }^{166}$ "Voluntary associations" are groups that people freely choose to join purely to advance their individual agendas; "communities" are groups that people may choose or not and are held together "by shared visions that constitute for each of them their personal identity." ${ }^{167}$ Many groups exhibit characteristics of both. The potential for disputes and the need to collaborate in relatively intimate settings suggest that a condominium cannot be understood solely as a voluntary association in which individuals combine for instrumental reasons only. In a residential complex, individuals literally have to live with each other. Purchasing a residential condominium unit involves entering into a community with some sense of shared purpose: to enable each unit owner to own, take care of, and enjoy a home in the complex. ${ }^{168}$ As well, condominium developments are going concerns that evolve over time. Fulfilling the purpose

166. Gregory S Alexander, "Dilemmas of Group Autonomy: Residential Associations and Community" (1989-1990) 75 Cornell L Rev 1.

167. Ibid at 26.

168. Commercial condominiums may more closely resemble a "voluntary association," depending on the character of the property and the businesses located there. 
of sustaining a harmonious community may therefore require adjustments, mediated through democratic decision-making. A purchaser of a unit cannot reasonably adopt a full-fledged property expectation that all their rights will be frozen at the time of purchase.

In this respect, the application of the oppression remedy from corporate law requires particular care. While this remedy began as a flexible and equitable one that had regard to oppressive and unfair conduct in general, courts in recent decades have narrowed its application. ${ }^{169}$ An action for oppression now succeeds when a minority can demonstrate that they had objectively reasonable expectations regarding their purchase of property and those expectations have been violated by majority action that was significantly unfair. ${ }^{170}$ If condominium is to survive and flourish, the qualifiers that the expectations be "reasonable" and that the violations be "significantly unfair" have a lot of work to do. The pluralist perspective provides a suitable framework to inform that work. In particular, as the Ontario court stated in McKinstry, "the court must balance the objectively reasonable expectations of the owner with the condominium board's ability to exercise judgment and secure the safety, security and welfare of all owners and the condominium's property and assets." ${ }^{171}$ Both courts and purchasers of units need to understand that purchasers' expectations are only one of many values to be considered.

Bankruptcy and corporate restructuring is another area of law that might provide useful analogies or ideas for condominium. In a bankruptcy, the usual rights of property are suspended and the bankrupt's assets vest temporarily in a trustee who liquidates or manages those assets for the benefit of creditors. ${ }^{172}$

169. Markus Koehnen, Oppression and Related Remedies (Toronto: Thomson Carswell, 2004) at 84-88 (tracing the development of the "reasonable expectations" test for shareholder oppression to Ebrahimi v Westbourne Galleries Ltd, [1972] 2 All E R 492 (HL). See also David S Morritt, Sonia L Bjorkquist \& Allan D Coleman, The Oppression Remedy (Aurora, ON: Canada Law Books Inc, 2004), ch 3 at 3-1. Morrit, Bjorkquist \& Coleman state that "in considering applications made pursuant to the statutory oppression provisions, courts rely heavily on the evidence of shareholder expectations in determining whether conduct has been oppressive or unfairly prejudicial."

170. 459381 BC Ltd v Strata Plan BCS 1589, 2012 BCCA 44, [2012] 4 WWR 475 [Dollan]; see discussion supra notes 83-89.

171. McKinstry v York Condominium Corp No 472 (2003), 68 OR (3d) 557 at 566, 127 ACWS (3d) 560. See discussion supra notes 83-94.

172. Bankruptcy and Insolvency Act, RSC 1985 c B-3, s 5(2)-(3). Also see generally Mr. Justice Lloyd W Houlden, Mr. Justice Geoffrey B Morawetz \& Dr. Janis P Sarra, Bankruptcy and Insolvency Law of Canada, 4th ed (Toronto: Carswell, 2005); Lazar Sarna, Law of Bankruptcy and Insolvency in Canada, revised ed (Toronto: LexisNexis, 2005) at 1-2. 
In a corporate restructuring under the Companies' Creditors Arrangement Act, ${ }^{173}$ creditors' rights to execute on debts are suspended while the debtor and creditors negotiate a restructuring under court supervision, which can result in sweeping changes to the debtor corporation's legal structure, ownership, and debts. ${ }^{174}$ The elaborate negotiations between interested parties in such proceedings, conducted with the help of temporary administrators and court oversight, provide a forum in which to work out flexible and viable solutions. When a complex proves to be commercially unviable, as in Royal, or where disputes lead to acrimony and gridlock, a restructuring mechanism might provide the best way forward. The dissent in Royal recognized this and was willing to read a type of restructuring remedy into the residual powers of the statutory scheme. Both BC and Ontario provide for a court-appointed administrator to manage the affairs of a complex in the event that the condominium corporation cannot function. ${ }^{175}$ However, the administrator's powers are limited and, in BC, the administrator may not take any action that normally requires a vote without first securing that vote. ${ }^{176}$ Strengthening this approach by providing express legislative authority for a more complex restructuring process could prove a very useful innovation. Such an innovation would also promote a pluralist approach to condominium, requiring highly contextual solutions that incorporate direct consideration of the values underlying the condominium.

Both BC and Ontario have recently undertaken reviews of their condominium legislation. In Ontario, the review process led to a "Stage Two solutions report" published in September 2013, ${ }^{177}$ and after further consultation with the public, to a proposed Protecting Condominium Owners Act. ${ }^{178}$ The Ontario review focused on five areas: consumer protection, financial management, dispute resolution, governance, and condominium management. ${ }^{179}$ The review was based on seven "values" that were identified as "essential to building successful condo communities": well-being, fairness, informed community members and

173. Companies' Creditors Arrangement Act, RSC 1985, c C-46, s 11.

174. Dr. Janis P Sarra, Rescue! The Companies' Creditors Arrangement Act, 2nd ed (Toronto: Carswell, 2013).

175. Condominium Act, supra note 14, s 131; SPA, supra note 14, s 174.

176. SPA, supra note 14, s 174(7).

177. Public Policy Forum, Growing Up: Ontario's Condominium Communities Enter a New Era: Condominium Act Review Stage Two Solutions Report (Ottawa: Public Policy Forum, September 2013).

178. Bill 106, An Act to amend the Condominium Act, 1998, to enact the Condominium Management Services Act, 2015 and to amend other Acts with respect to condominiums, 1st Sess, 41st Leg, Ontario, 2015 (first reading 27 May 2015).

179. Public Policy Forum, supra note 182 at 5. 
stakeholders, responsiveness, strong communities, financial sustainability and effective communication. ${ }^{180}$ The reviewers emphasized that "condos are much more than legal entities. They are self-governing communities." 181 Recognizing that condominium issues are "not just legal or technical" but "often... are about relationships between a varied and often disparate group of interests," 182 the reviewers adopted "an approach based on collaboration and compromise." 183 In the end, the recommendations in the report focused on consumer protection through disclosures to buyers, protecting against fraud in condominium governance, and dispute resolution mechanisms, rather than on property entitlements. In fact, the report says little about property rights, focusing instead on the need to address multiple values and to create viable condominium communities with long-term relationships between owners.

The new Protecting Condominium Owners Act largely follows the recommendations in the Stage Two solutions report. ${ }^{184}$ One important change is the creation of a new "Condo Authority," an arms-length administrative agency focused on education and dispute resolution. In particular, the Condo Authority includes an administrative tribunal to adjudicate a variety of condominium disputes, including disputes regarding the enforcement of declarations, by-laws and rules. The tribunal would provide a cheaper and more informal process than going to court. As a means of promoting harmony through the quick and informal resolution of disputes, the tribunal is aligned with a pluralist vision of property in the condominium, rather than a strict, rule-based vision that places property rights first.

In $\mathrm{BC}$, the review of strata property legislation by the British Columbia Law Institute (BCLI) is ongoing. The Phase One report, published in November 2012, identifies seven areas to be examined during Phase Two: fundamental changes to stratas, "complex stratas," leasehold stratas, common property, governance issues, insurance issues, and land-title issues. ${ }^{185}$ As of this writing, the BCLI has published a report on only one of these areas, fundamental changes

180. Ibid at 15 .

181. Ibid at 10 [emphasis in original].

182. Ibid [emphasis in original].

183. Ibid [emphasis in original].

184. Protecting Condominium Owners Act, SO 2015, c 28. For a useful overview of the Act, see Consumer Protection Ontario, "Proposed condo changes" (8 September 2015), online: Government of Ontario <http://www.ontario.ca/page/proposed-condo-changes\#section-1>.

185. British Columbia Law Institute, Report on Strata Property Law: Phase One, BCLI Report No 70 (Vancouver: BCLI, 2012) [BCLI]. 
to stratas. ${ }^{186}$ Fundamental changes, complex stratas, and common property are more likely to involve questions about the conception of property than the issues canvassed in the Ontario review. "Fundamental changes" refer to winding up and dissolution, amalgamations of strata complexes, and major changes to a strata plan. Complex stratas refer to multi-use strata complexes, which may have "residential, commercial, industrial, recreational, or other uses." 187 The review of common property is to be focused on "perceived uncertainties in the legislation," as "despite the essential importance of common property to stratas, there appear to remain some basic issues concerning its character that would benefit from clarification." 188 The review of disputes over common areas in this article supports this assertion. While the BCLI review process is still at an early stage, its findings and recommendations are likely to engage the question of how best to understand property rights in condominium.

Looking to the future, it is likely that condominium will continue to present new challenges to traditional notions of property. One topic making its way through the courts at present is cigarette smoking. ${ }^{189}$ Many condominium corporations in both Ontario and BC have passed by-laws to prohibit smoking, not just in common areas or outdoor patios, but also inside individual units. Judicial pronouncements on whether such rules are "reasonable" or "significantly unfair" will arrive soon. Such cases will again require courts to consider the nature of property in condominium. A utilitarian approach requires a cost/benefit analysis; a deontological approach requires consideration of the rights of property and the reasonable expectations of owners upon purchase. A pluralist approach requires more. For smoking, this would involve considering the impacts of smoking on the other owners and the impacts of a smoking ban for those who want to smoke or are struggling with tobacco addiction. Further, a pluralist approach may not lead to a one-size-fits-all solution; perhaps the proximity of units, the structure of a complex's ventilation system, and the general acceptance of smoking in the greater community are all factors to consider. The power of the pluralist approach is that it allows for the entire context of the matter to be taken into consideration, and a greater probing of the individual and communal interests at stake.

186. British Columbia Law Institute, Report on Terminating Strata (February 2015), online: <www. bcli.org/wordpress/wp-content/uploads/2015/02/2015-02-20_BCLI-SPL-Ph2-Report-on-

Terminating-a-Strata-FINAL.pdf $>$. For the discussion of the report see supra notes 150-153.

187. BCLI, supra note 190 at 20.

188. Ibid at 23.

189. Jason Proctor, "Smoker-rights battle heads to B.C. Supreme Court", $C B C$ News (7 September 2015) online: <www.cbc.ca/news/canada/british-columbia/ smoker-rights-battle-heads-to-b-c-supreme-court-1.3216557>. 